\title{
REMEMBERING URBAN TRAUMA: ST PETERSBURG AND NIJMEGEN IN THE SECOND WORLD WAR
}

Niek van Ansem ${ }^{1}$ (a), Louise David ${ }^{2}$ (a), Carien van Eekhout ${ }^{3}$ (a), Marit Leijnse ${ }^{4}$ (a), Savannah Mellendijk ${ }^{5}$ (a), Kees Oost ${ }^{6}$ (a)

(a) Radboud University. Nijmegen, The Netherlands.

\begin{abstract}
The issue of the memory of collective trauma has rarely been analyzed in cross-cultural research. Urban trauma, in particular, is a relatively unknown concept. Never before has the memory of urban trauma of the cities of St Petersburg and Nijmegen in relation to the Second World War been compared in the academic realm. This article sets out to create a juxtaposition of St Petersburg and Nijmegen in terms of their Second World War traumas and the way these traumas are represented and commemorated in both cities. The authors examine the meaning-making role that experts play within the remembrance culture of St Petersburg and Nijmegen. A thick description of conducted field research and interviews with experts are used in order to thoroughly compare the experts' approach to the remembrance cultures. This article aims to compare and translate the way in which different types of memory of trauma relate to the same event. It establishes that although there are distinct differences between the two cities, experts deal with researching the commemoration of trauma in a similar manner. This study reveals uneasy questions, blind spots and taboos of commemorating urban trauma in both Russia and the Netherlands.
\end{abstract}

\section{Keywords}

Urban trauma; Nijmegen; St Petersburg; Memory; Remembrance Culture; Experts; Second World War; Taboos; Blind Spots

This work is licensed under a $\underline{\text { Creative Commons «Attribution» } 4.0 \text { International }}$ License.

1 Niek.vanAnsem[at]student.ru.nl

2 Louise.David[at]student.ru.nl

3 Carien.vanEekhout[at]student.ru.nl

4 Marit.Leijnse[at]student.ru.nl

5 Savannah.Mellendijk[at]student.ru.nl

6 Kcsoost[at]gmail.com 


\section{ВСПОМИНАЯ ГОРОДСКУЮ ТРАВМУ: САНКТ-ПЕТЕРБУРГ И НЕЙМЕГЕН ВО ВРЕМЯ ВТОРОЙ МИРОВОЙ ВОЙНЫ}

ван Ансем Ник ${ }^{1}(\mathrm{a})$, Давид Луиза ${ }^{2}(\mathrm{a})$, ван Экоут Карин ${ }^{3}(\mathrm{a})$, Лейнсе Марит ${ }^{4}$

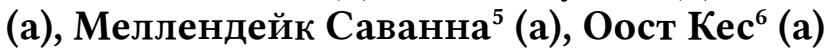

(a) Университет Неймегена. Неймеген, Нидерланды.

\section{Аннотация}

Вопрос памяти о коллективной травме редко находился в фокусе кросскультурных исследованиях. Городская травма, в частности, является еще относительно малоизвестным понятием. До сих пор память о городской травме таких городов, как Санкт-Петербург и Неймеген, в связи со Второй мировой войной никогда не сравнивалась в академической сфере. В данной статье авторы пытаются провести сравнение полученного во время Второй мировой войны травматического опыта жителей Санкт-Петербурга и Неймегена и того, как эти травмы представлены и увековечены в этих городах. В статье предпринята попытка проследить смыслообразующее влияние, которое оказывают эксперты на систему памяти в Санкт-Петербурге и Неймегене. Для тщательного сравнения подходов экспертов к культуре памяти используется подробное описание проведенных полевых исследований и интервью с экспертами. Целью данной статьи является сравнение и трансляция того, как различные типы памяти о травме соотносятся с одним и тем же событием. В статье демонстрируется, что, несмотря на различия между двумя городами, в подходах экспертов, занимающихся исследованием памяти о травме, можно выявить аналогичные тенденции. Данное исследование затрагивает непростые вопросы, "слепые пятна" и табу в отношении памяти о городской травме как в России, так и в Нидерландах.

\section{Ключевые слова}

Травмы в городах; Неймеген; Санкт-Петербург; Память; Культура памяти; Эксперты; Вторая мировая война; Табу; слепые пятна

Это произведение доступно по лицензии Creative Commons «Attribution» («Атрибуция») 4.0 Всемирная

1 Niek.vanAnsem[at]student.ru.nl

2 Louise.David[at]student.ru.nl

3 Carien.vanEekhout[at]student.ru.nl

4 Marit.Leijnse[at]student.ru.nl

5 Savannah.Mellendijk[at]student.ru.nl

6 Kcsoost[at]gmail.com 


\section{INTRODUCTION}

On May 15th, 1940, the Dutch army surrendered to Nazi Germany, a mere five days after the German invasion of the Netherlands began. In the years of occupation that followed, life in the small, Dutch border town of Nijmegen was not much different from that in any other city in occupied territory. That was until the 22nd of February 1944, when Nijmegen was bombed by American aircraft; the bombing killed at least 770 people, making it the second deadliest bombing raid in the Netherlands after the 1940 bombing on Rotterdam by German airplanes (Rosendaal, 2014). To make matters worse, Nijmegen became a front city once the Allied forces launched Operation Market Garden in September 1944. The liberation of the city came at the cost of approximately 800 citizens' lives (Rosendaal, 2014). By that time, the Soviet metropolis Leningrad (today: St Petersburg) had been liberated by the Red Army after having been besieged by the German Wehrmacht for 872 days. Leningrad's wartime experiences were traumatic from the very beginning: the death toll of the Leningrad blockade reached well over one million victims (Bidlack \& Lomagin, 2012).

Especially in terms of suffering, St Petersburg and Nijmegen are probably incomparable, yet the impact that the blockade and Allied bombing had on the respective cities can be compared. Both events simultaneously left great gaps in the cities' histories but also added to these histories the story of war on an unprecedented scale. Notwithstanding the geopolitical aspects of the Second World War, the difference between a hostile invasion and prolonged blockade versus enemy occupation and Allied bombing is at the center of this research, which ultimately focuses on the concept of "urban trauma." Both cities and their citizens suffered this urban trauma, which as a concept can be defined as a collective trauma shared by the wartime inhabitants of the city, the generations thereafter, and, in some respects, the city itself. Whenever a subject is considered a trauma, it can be expected to contain aspects that are considered taboo or that are often forgotten - either subconsciously or because they are actively suppressed. What is remembered or forgotten depends greatly on political and cultural contexts. These are the contexts in which the process of giving meaning to historical events takes place. This meaning-making process is driven by many different actors who all have one thing in common: a desire to highlight certain aspects of the narrative of the event. 
This desire to highlight certain aspects of the war is evident in both the Dutch and Russian remembrance cultures. The remembrance culture of Russia changed significantly after the collapse of the Soviet Union, as topics such as cannibalism, Stalin's crimes and food rationing came to light (Kirschenbaum, 2006). The need to protect the glorious image of Leningrad's defenders was undoubtedly still present, yet personal narratives and aspects of everyday life now became more apparent in discourse on the memory of the Blockade (Kirschenbaum, 2006). A similar change occurred in the Netherlands, where initially commemorations were organized and monuments were built by and for the resistance to promote a heroic narrative. It was not until the early 1960s when questions were raised about the extent of this resistance towards the occupiers. Moreover, it was not until the 1970s that the suffering of the Jewish community was remembered during official commemorative practices (Van Ginkel, 2011). Ido de Haan, author of the influential book $\mathrm{Na}$ de Ondergang (After the downfall), argued that "the Jewish community was depicted as passive, helpless people, often nervous and therefore unreliable. Besides this, they were barely ever given a voice or face" (1997, p. 114). In the end, the remembrance culture of the Netherlands has made more room for the commemoration of civilian and social history, although military history is still highly present.

This research project specifically focused on experts' views and their role in influencing and adding meaning to the remembrance cultures of Russia and the Netherlands. In doing so, the following question was examined: How do experts approach the memory of urban trauma in Nijmegen and St Petersburg with regard to the Second World War? The methods used to answer the research question were thick descriptions of conducted field research and expert interviews.

\section{MEMORY AND HISTORY}

With regard to memory and history, the rhetoric of "collective memory" is especially interesting for our research. A collective memory belongs not to an individual, but to a larger social unit, such as a family, community, or nation, which attaches special meaning to a certain event from the past. The notion of collective memory was first coined by the French philosopher Maurice Halbwachs (1980), who advanced the thesis that a certain group can have a collective memory and that this is dependent upon the framework within which this group is situated in a society. In addition, Halbwachs also recognized the role of the individual participant in the process of collective remembrance. While collective memory 


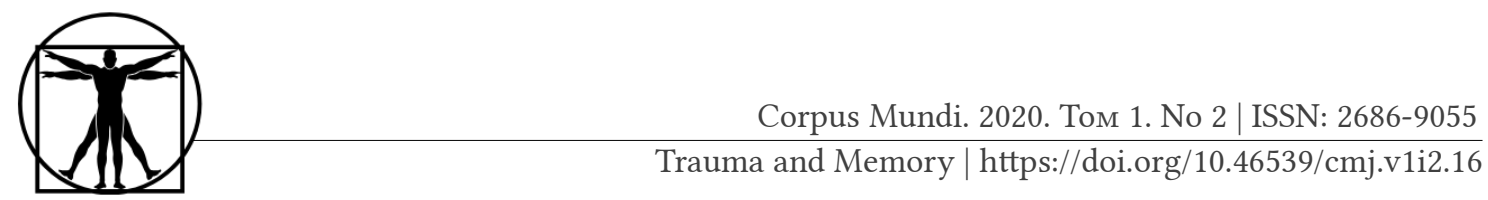

endures in a coherent body of people, it is individuals as group members who remember. When creating memories, the individual self and the collective are closely intertwined.

This connection is also apparent with the idea of "postmemory," as proposed by the American linguist Marianne Hirsch (2012). Postmemory describes the relation that, for example, the children of those who experienced the events have with the personal, collective, and cultural memory of those who came before. They only remember by means of the stories, images, and behaviors among which they grew up, as is currently the case for many citizens of Nijmegen and St Petersburg, but these experiences were transmitted to them so deeply and effectively as though they constituted memories in their own right. The idea of postmemory therefore clearly relates to the topic of urban trauma, since, if connected to Hirsch's and Halbwachs' theories, it becomes possible to relate urban trauma to the children and, to some extent, the grandchildren of those who actually experienced the war. Furthermore, from a collective historical point of view, it is possible to relate the notion of urban trauma to the cities, in general, since the memory of trauma that was conveyed to the next generations has been of consequence to the cities' contemporary identities. Hence, this study integrates the idea that collective memory is socially framed and the belief that traumatic events continue to influence postgenerations.

\section{THE NOTION OF URBAN TRAUMA}

Within the field of sociology, traumas are primarily studied as collective phenomena. Among sociologists there is a debate about what exactly constitutes a "trauma" (Taylor Woods, 2019). On one side of the debate are academics such as Arthur Neal (1998) who believe that there are certain events that are labeled as traumas because of inherent traumatic characteristics. On the more constructivist side of the debate are those that believe that cultural representation of the past is the leading element in what is being labeled as a trauma, such as Jeffrey Alexander. Alexander (2004) therefore refers to traumas as "cultural traumas." A middle stance in this debate is taken by Ron Eyerman and Dominik Bartmanski (2011), who argue that the inherently traumatic nature of some events, makes them more likely to subsequently being represented as a cultural trauma. The initial shock-effect that an event brings about, can have the enduring influence that is necessary for grassroot-movements to arise. Such grassroot- movements can subsequently play a vital role in the meaning-making process (Eyerman and Bartmanski, 2011). 
With regard to this meaning-making process Eyerman refers to actors engaged in this process as "carrier groups" (Eyerman, 2011; 2012). Eyerman uses a broad definition regarding who are part of these carrier groups, including academics, writers, journalists, filmmakers and politicians. Persons or associations that can be labelled as carrier groups are often highly emotionally invested in the event at hand, which is why they choose to engage in the meaning-making process. On the other hand, Bradford Vivian (2017) discusses how commemorative initiatives can also be employed to serve political motives. On this subject, Vivian quotes Margalit: "It is not the question whether collective memory is manipulated. It usually is. The interesting question is why the manipulators choose to manipulate" (2017, p. 24). This shows that it is useful to make a distinction between emotional and more pragmatic motives to commemorate and hence to make a distinction between "carrier groups" and "stakeholders".

Cultural traumas can thus be said to refer to discursive responses to the disruption of a society by a traumatic event, which creates the need for a process of meaning-making (Smelser, 2004; Alexander et. al., 2004; Eyerman et. al., 2011). When applying the concept of "cultural trauma" to the historical cases of St Petersburg and Nijmegen, it becomes clear that traumas can also be linked specifically to subnational communities, such as urban populations. The events that took place in St Petersburg and Nijmegen set those cities apart from the rest of the country, in terms of their war experience. This separation of experiences between nation and city has arguably intensified due to the low level of post-war recognition of the traumatic events. In Russia, according to one of our experts, the Soviet government initially suppressed witness accounts that did not fit the heroic narrative (personal communication, 28 January 2020). In the Netherlands, the post-war reconstruction era created an atmosphere where there was little interest in the normative value of commemoration (Rosendaal, 2014, pp. 140-142). In this climate, the bombardment of Nijmegen - unlike the one in Rotterdam - disappeared from the general public's post-war memory.

Therefore, the traumatic memories of the Leningrad blockade and the bombardment of Nijmegen arguably constitute an "urban trauma," existing parallelly to the national traumas of the Second World War. The concept of urban trauma can, thus, be said to simply refer to a cultural trauma tied specifically to a city or municipality. 


\section{METHODOLOGY}

With respect to both cities, there exists a division between the actual event (historical context), the narrative about the event (e.g. in books, museums, monuments and documentaries), and the differences and similarities found within experts' (academics, journalists, museum directors, teachers, and selected other stakeholders) opinions on the remembrance culture and its presented narrative. This study will use this division to simplify the difficult task of comparing the remembrance cultures of two extremely different cities.

It incorporates a bottom-up perspective to existing research on the remembrance culture and urban trauma in relation to World War II for both the case studies of Nijmegen and St Petersburg. The data of the research will consist of qualitative data gathered from existing literature, an observational study and semi-structured interviews with experts. The semi-structured approach to the interview will yield information that can be compared across interviews (Hill et al., 2005; Hill, Thompson \& Williams, 1997) but still allows flexibility to ask additional into-depth questions in particular areas that are possibly different across individuals (DiCicco-Bloom \& Crabtree, 2006; Flick, 2002). The interviews have been coded and analyzed on two levels: to assess the differences and similarities in experiences and perceptions of remembrance culture and urban trauma between experts, and to analyze how academics reflect on remembrance culture and urban trauma.

Besides the interviews, the "thick description" method is used to record observations gathered during a trip to St Petersburg and excursions in Nijmegen. This field research includes visits to museums, monuments and ceremonies, but also brief "interviews" of civilians. The thick description is a method that was introduced by philosopher Gilbert Ryle in 1949 (Bambrough, 1994) and was further developed by the anthropologist Clifford Geertz (Geertz, 1973). For outsiders engaging with a foreign culture it entails evaluating upon a situation or event in its entirety, using this evaluation to come to a detailed interpretation of a certain phenomenon in that culture (Lincoln \& Guba, 1985). In this paper, this method will be used to organize visits to museums and monuments, observations at commemoration ceremonies, and similar activities.

\section{PLACES OF MEMORY: MONUMENTS, MUSEUMS AND RITUALS}

It is possible to divide the memory of the Second World War and how this memory reflects the trauma of a city and its citizens in three 
parts, namely space, society, and individual. These parts are closely intertwined within places of memory. Places of memory, such as monuments, museums or events, signify cultural landmarks from a shared past (Legg, 2005). In both cities, people mark their memory of the war time events. In Nijmegen, the most obvious example is the "Fire Limit Route," which consists of many tiny plaques fixed in the streets of the city center that symbolize the impact zone of the bombardment. These plaques mark not only the place of trauma, but also form a place for rituals, both on a communal and private level. For example, during last year's commemoration runners ran along the route with torches paying tribute to the victims of the bombardment.

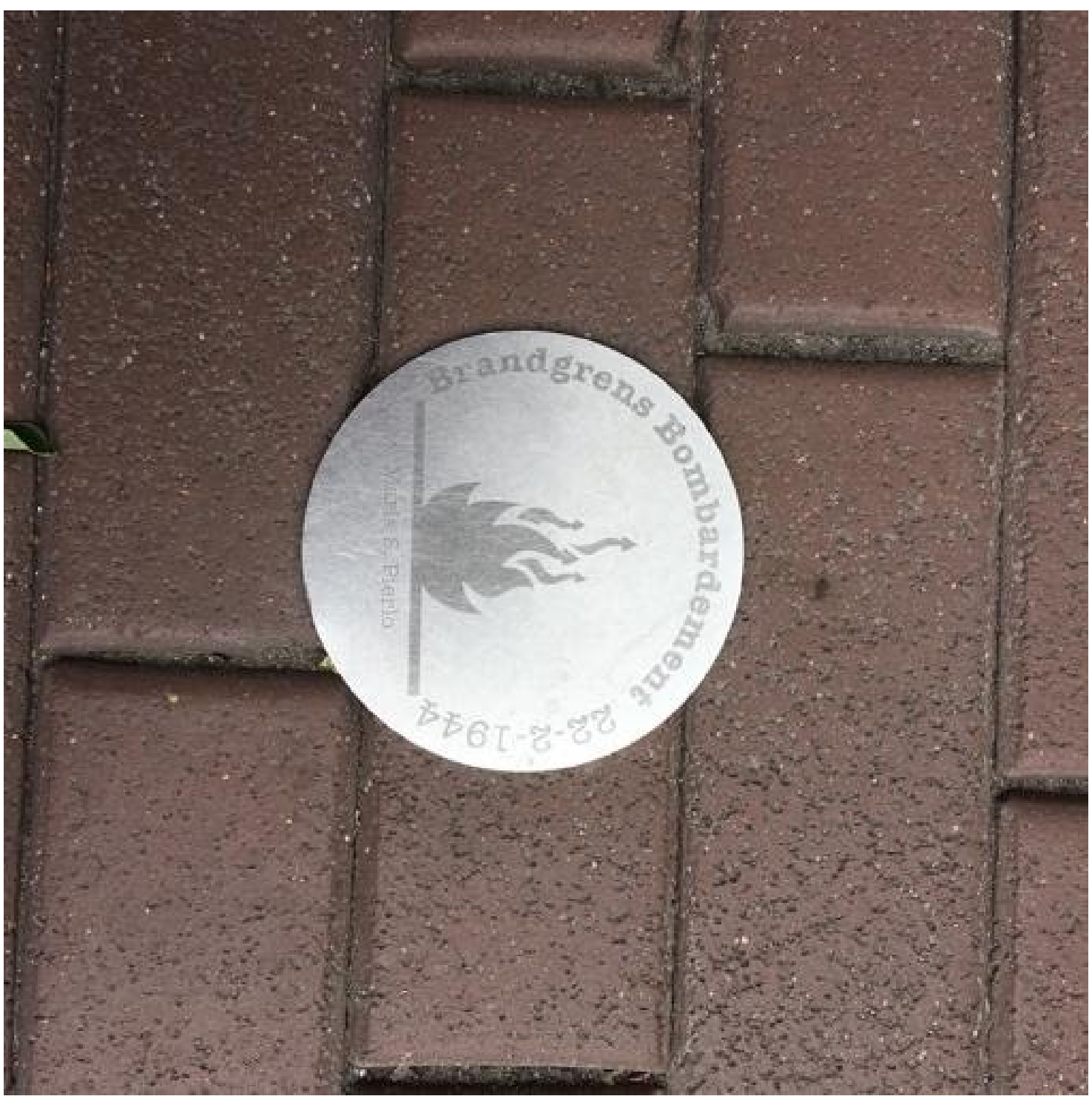

Figure 1. One of 800 "Fire Limit" plaques, equal to the number of victims of the bombardment (own photo) 

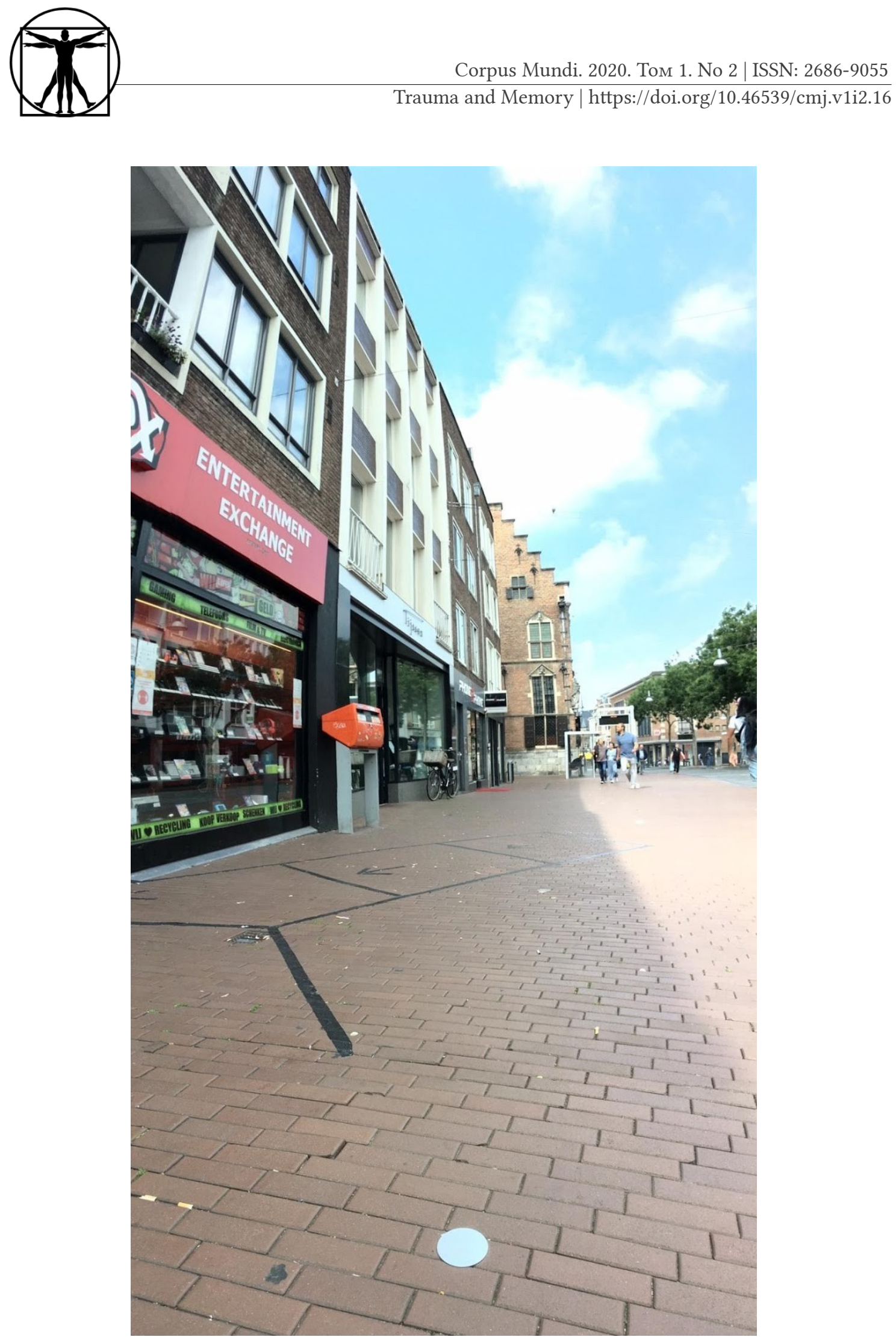

Figure 2. The "Fire Limit Route" shows the difference between the traditional architecture (in the back) and post-war buildings (on the side). In this picture, the route ends at the traditional 16th century Dutch mansion, which used to be city hall (own photo) 
The marking of a place with plaques in order to remember an event can also be found in St Petersburg. For example, the inscription "Citizens, during shelling this side of the street is the most dangerous" that appeared on the streets of Leningrad during the siege of the city and served as a public warning message. Although the warnings initially disappeared, over time the inscriptions were recreated and accompanied by a memorial plaque. Just as in Nijmegen, these plaques function as sites of commemorations, as in January 2020 St Petersburg's governor laid flowers at the inscription on Nevsky Prospect.

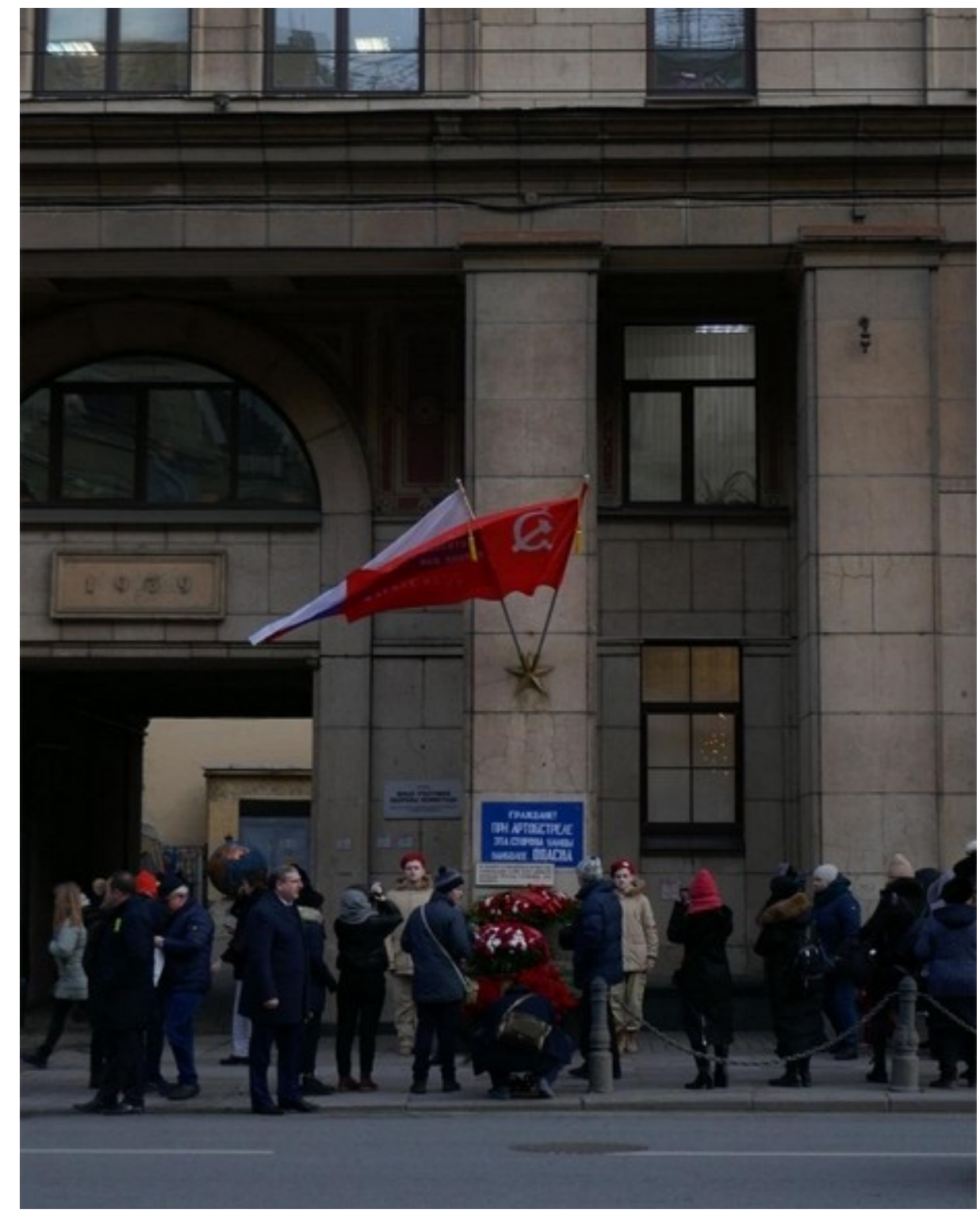

Figure 3. "Citizens, during shelling this side of the street is the most dangerous." Commemoration on the 27 th of January (own photo). 


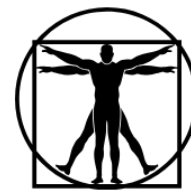

In contrast to these sites of memory, monuments do not mark the place of memory, but express the ritualized space of memory. The "Monument to the Heroic Defenders of Leningrad" on Victory Square powerfully depicts the story of the great feat of the people of Leningrad and the soldiers at the front.

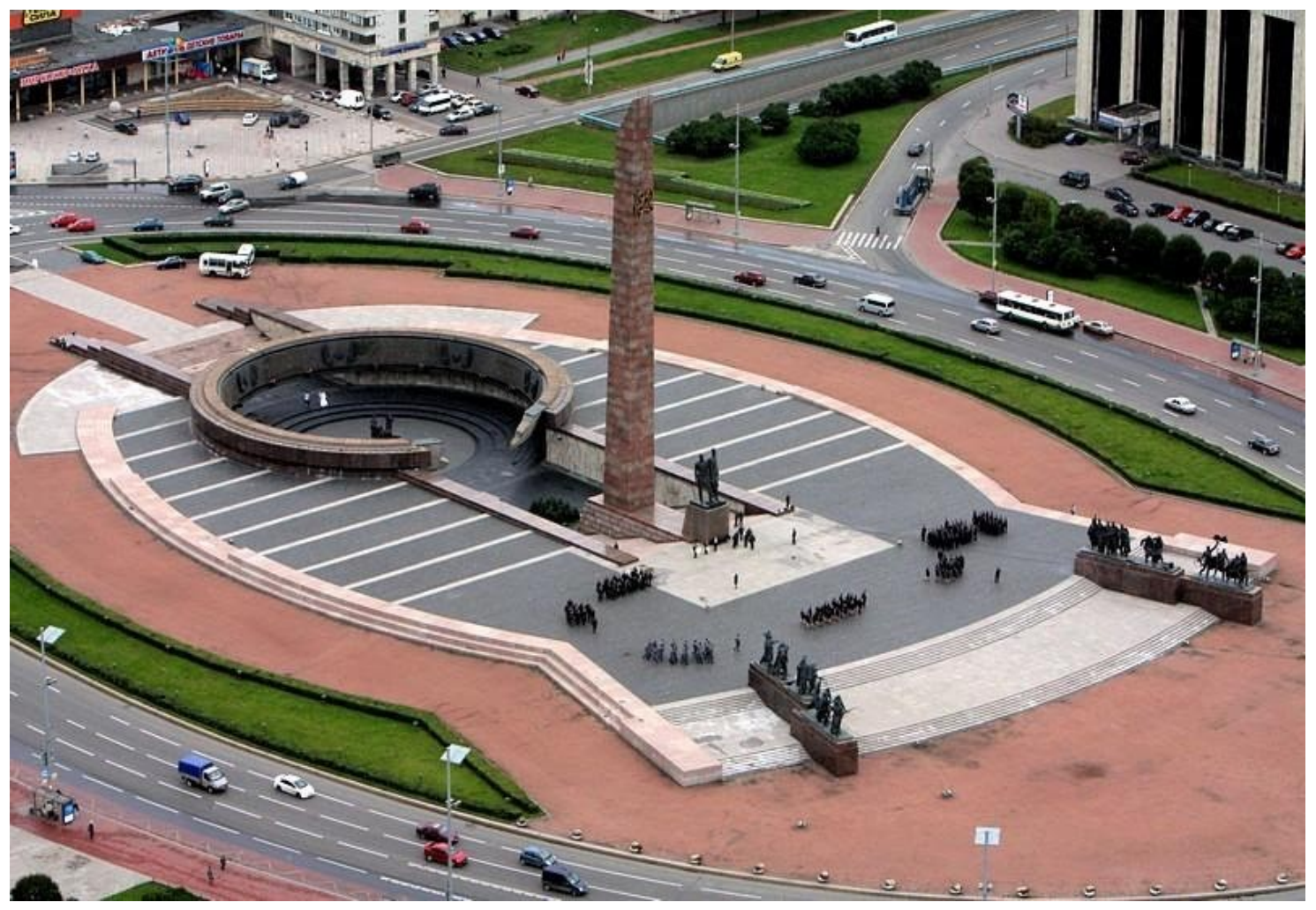

Figure 4. The "Monument to the Heroic Defenders of Leningrad" on Victory Square ("Monument to the Heroic Defenders of Leningrad," n.d.)

Similarly, in Nijmegen, the "Flag Bearer" depicts Jan van Hoof, a member of the resistance best known for saving the city's most important bridge from being destroyed by the Germans. The memorial, however, represents more than one act of bravery. It symbolizes the freedom of the inhabitants of the city. Located at the side of one of the central highways, almost everyone visiting the city rides past the memorial, in a similar way to the monument in St Petersburg.

When comparing the war monuments in both cities, there are several conclusions to be drawn. One is that the monuments in St Petersburg are generally larger in size. In addition, the monuments in St Petersburg are located on more prominent spots than in Nijmegen. Even though the "Flag Bearer" attracts the attention of visitors entering the city from the riverside, this is generally not the case. A good example of this is "The 
Swing", which is located on the place where a number of schoolchildren died during the bombing of the city. However, due to it being located in a small square surrounded by trees, shops, and lunchrooms, it is not easily spotted from a distance.

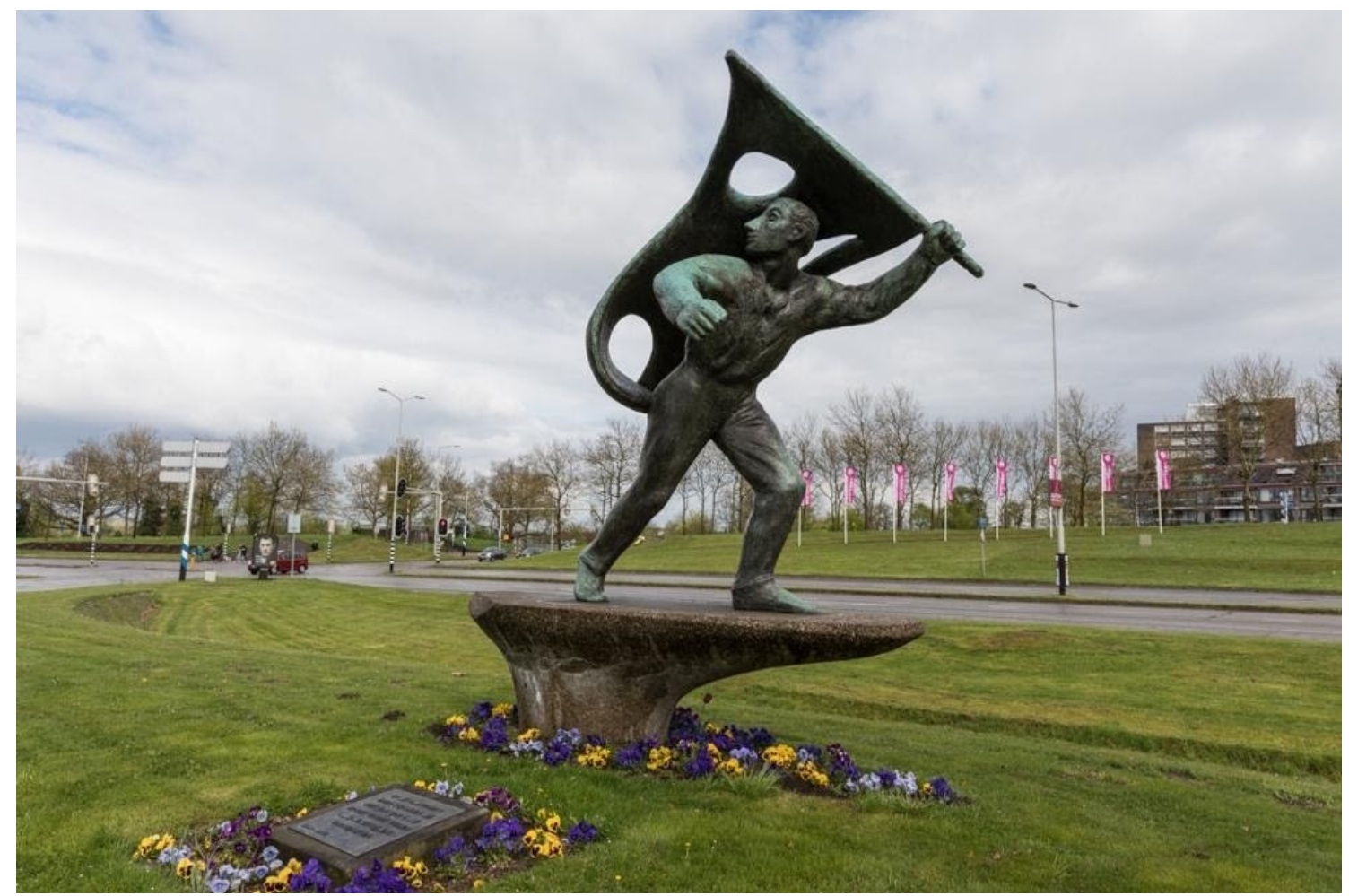

Figure 5. Jan van Hoof as "The Flag Bearer" ("Verzetsmonument "De Vaandeldrager," n.d.)

When comparing the war monuments in both cities, there are several conclusions to be drawn. One is that the monuments in St Petersburg are generally larger in size. In addition, the monuments in St Petersburg are located on more prominent spots than in Nijmegen. Even though the "Flag Bearer" attracts the attention of visitors entering the city from the riverside, this is generally not the case. A good example of this is "The Swing”, which is located on the place where a number of schoolchildren died during the bombing of the city. However, due to it being located in a small square surrounded by trees, shops, and lunchrooms, it is not easily spotted from a distance. 

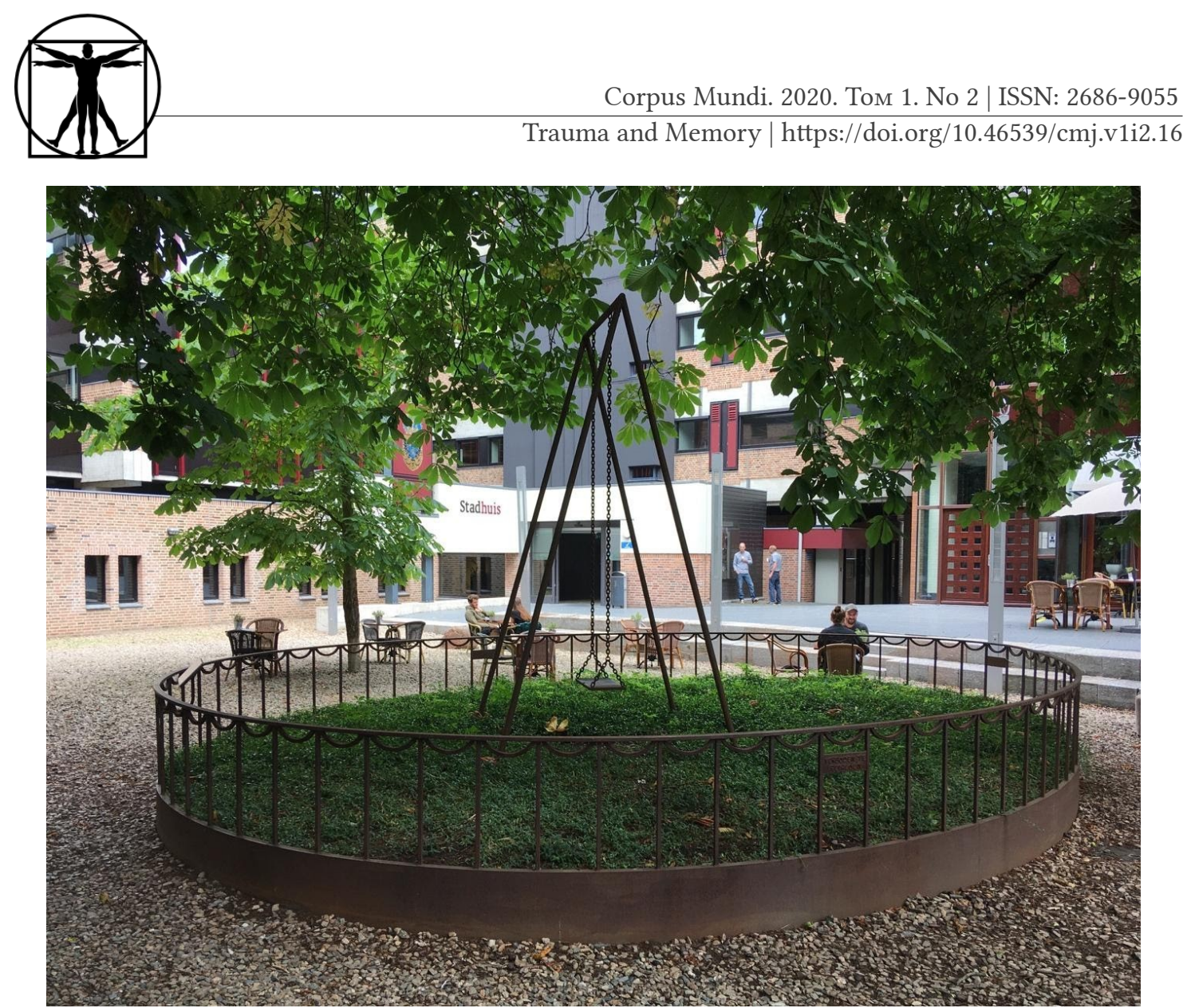

Figure 6. The "swing" monument is located inconspicuously (own photo)

Although both St Petersburg and Nijmegen have many war monuments scattered over the city, the monumental value of war cemeteries heeds particular attention. These places of memory may also fulfil a function of ritualization for state cults. While the Piskariovskoye cemetery in St Petersburg is an enormous graveyard that attracts the attention of a large number of visitors, the cemetery at the Graafseweg in Nijmegen looks like any other cemetery and is easy to miss. The graveyard at the Graafseweg already existed before the war, therefore the exterior of the cemetery only provides minor indication that it is the final resting place of war victims. Over time, however, some small sized monuments have been added, often on a private initiative, yet the most notable of these monuments was only placed in 2006, a year after public historian Bart Janssen published his locally famous book De Pijn die Blijft (The Pain that Remains, 2005), in which he raised attention for the bombardment and the mass grave that is situated at the cemetery on the Graafseweg. In fact, via archive research he even (re-)identified the existence of another mass grave at the cemetery, raising more questions with regard to the "forgetfulness" of the local authorities with respect to remembering the bombardment's victims. 
Corpus Mundi. 2020. Tom 1. No 2 | ISSN: 2686-9055

Травма и память | https://doi.org/10.46539/cmj.v1i2.16
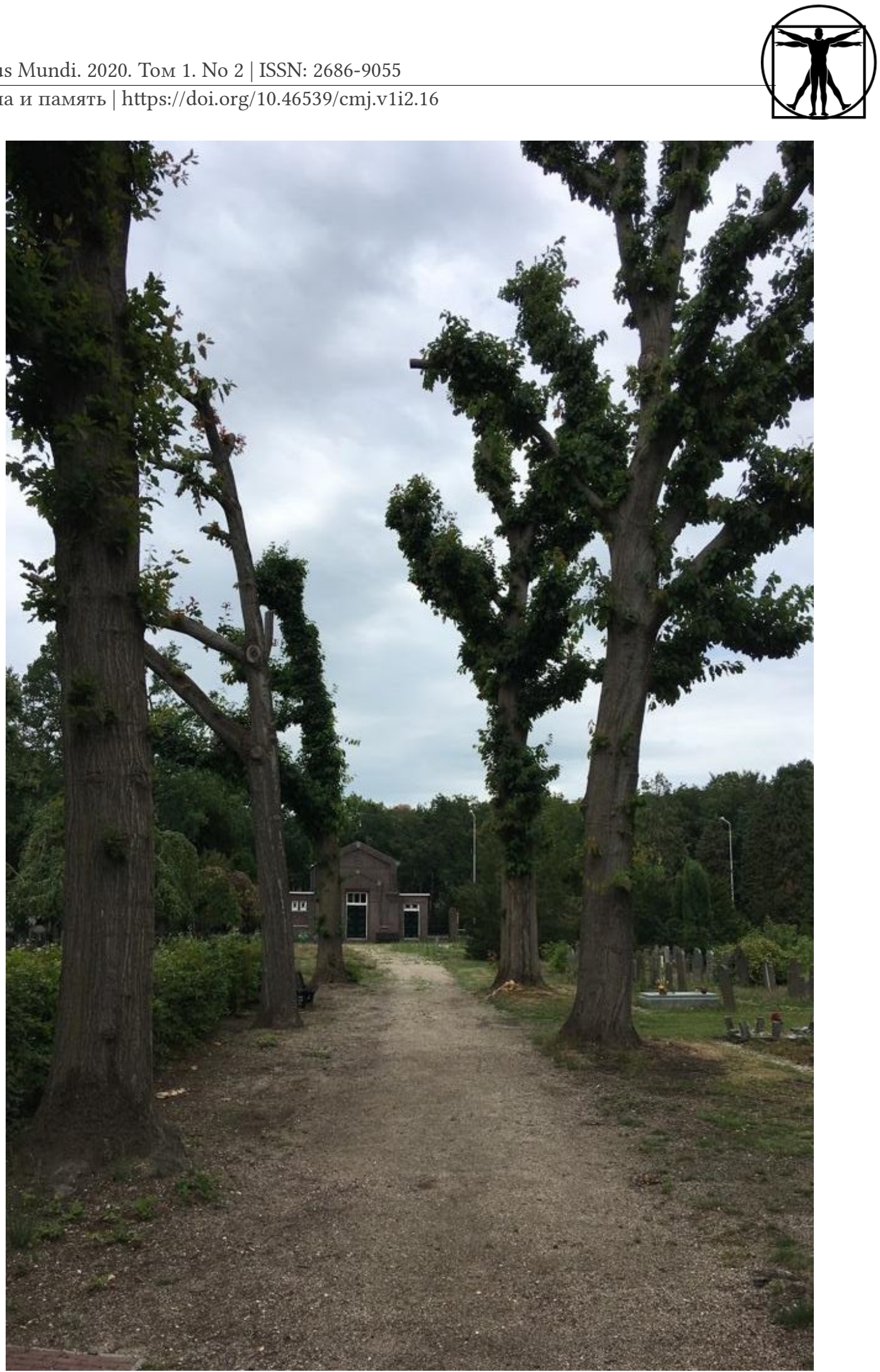

Figure 7. The cemetery at the "Graafseweg" (own photo) 

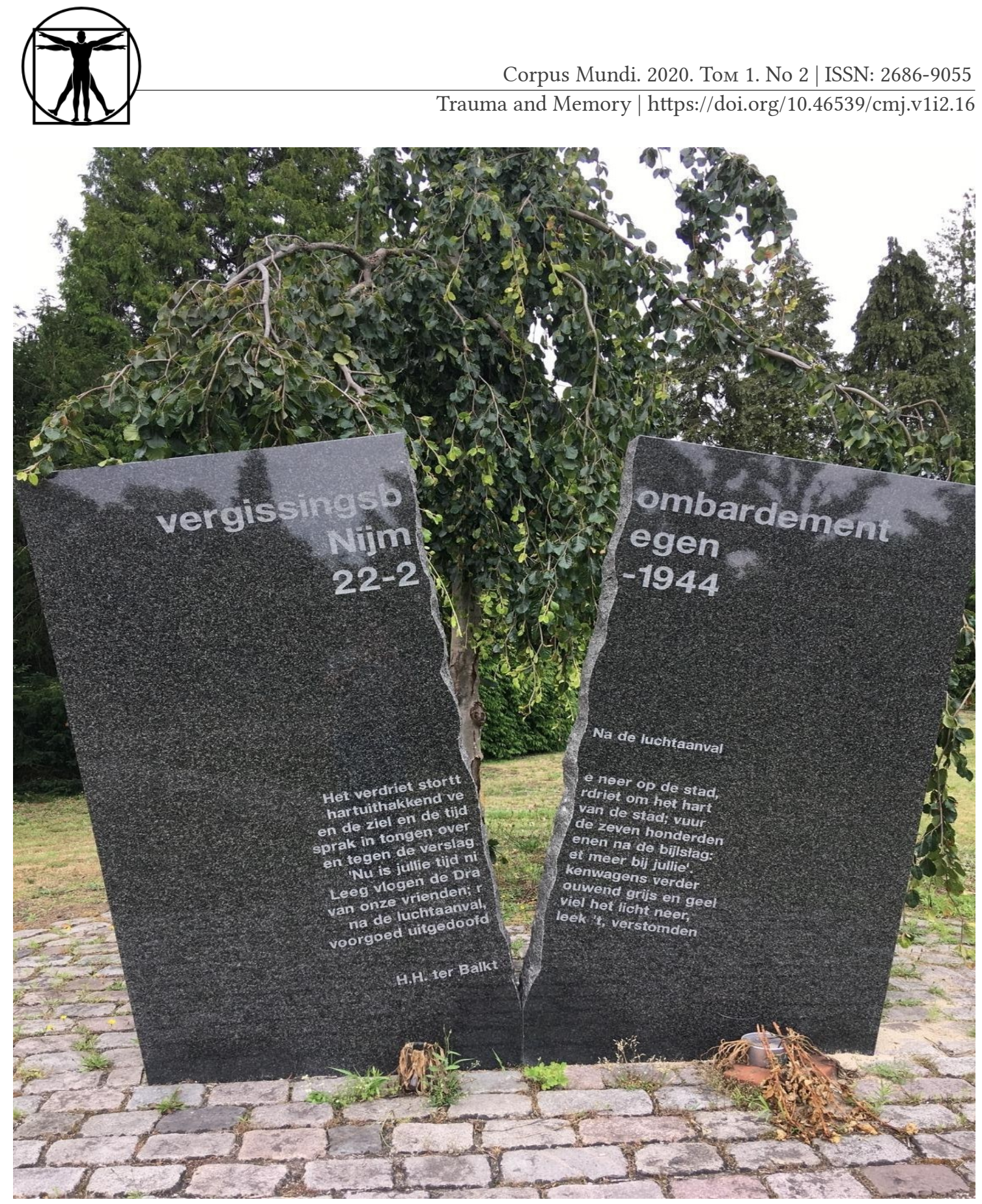

Figure 8. The 2006 memorial for the victims of what was at that time still known as "a bombardment by mistake," which is also the name of the memorial. Recent research by Joost Rosendaal (2014) has concluded that instead of a bombardment by mistake, the US aircraft more likely dropped the bombs out of opportunistic motives (own photo). The ripped apart stone represents the destruction that the bombardment wreaked (own photo) 


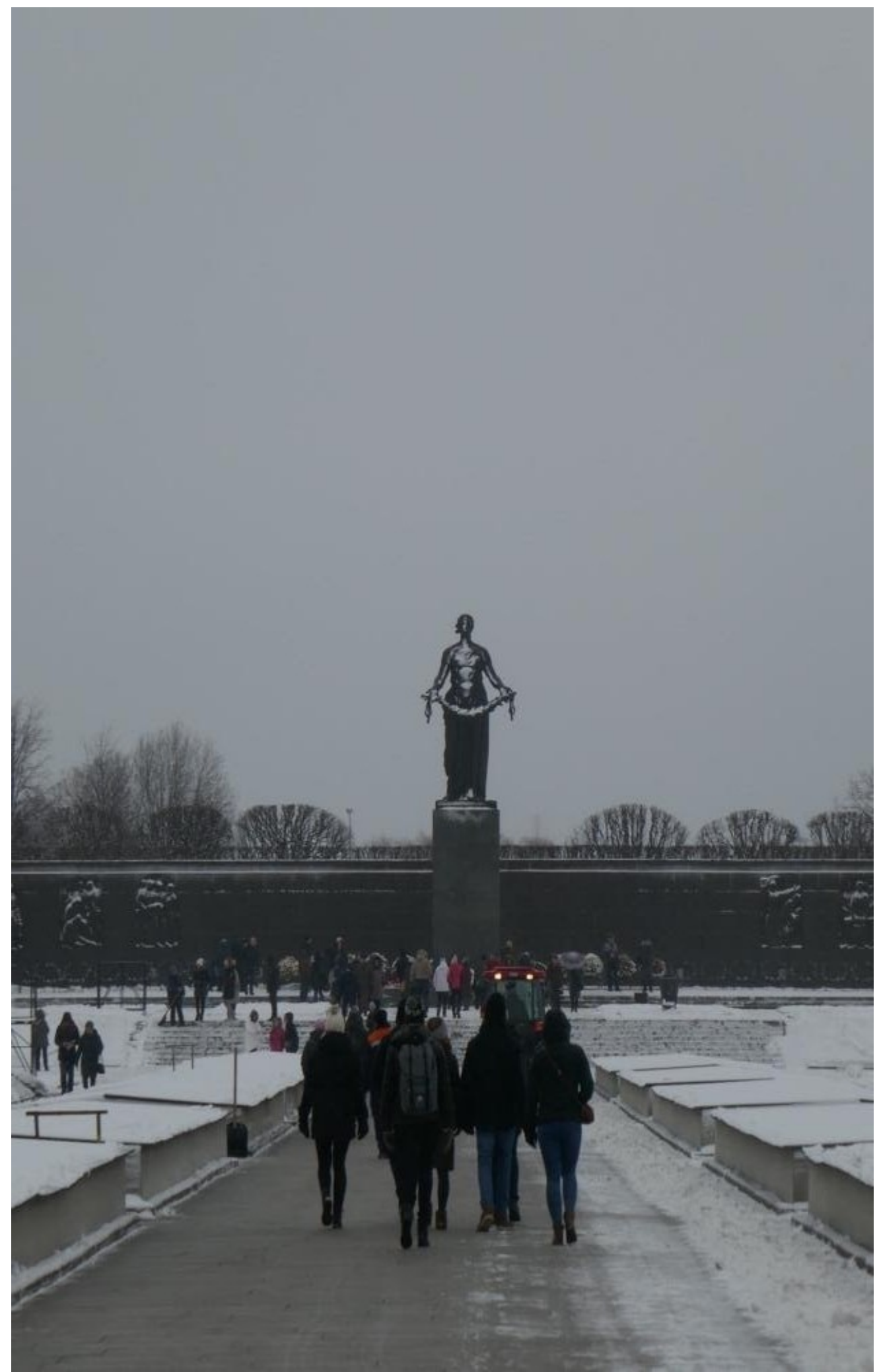

Figure 9. Piskariovskoye Memorial Cemetery. The statue depicts Mother Russia (own photo) 


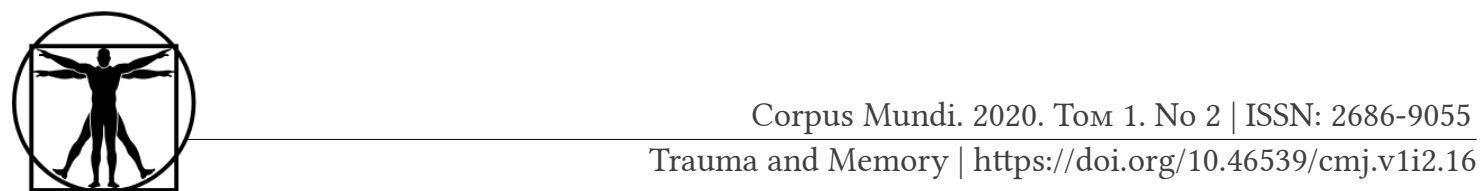

With regard to museums, the comparison between St Petersburg and Nijmegen reveals a clear division in what is remembered. At its opening shortly after the war, the oldest museum about the siege, which is currently called the "State Memorial Museum of the Leningrad Defense and Blockade," focused mainly on the military aspect of the blockade. This was due partly because shortly after the war there were simply more artifacts available related to this topic. Examples of these artifacts are military vehicles, weapons, and other material which became superfluous when war ends. Another reason was that the museum's curators feared Stalin's retribution if they were to emphasize the suffering of civilians and mistakes made by the government (personal communication, interviewee $\mathrm{K}$, 30th January 2020). Eventually, it was closed in 1949 and burned down under mysterious circumstances soon afterwards. It took decades before the State Memorial Museum opened its doors again in 1989 and it has remained open ever since. Hence, it remains a difficult task for museums to correctly and inclusively educate their audiences. Children, specifically, suffer from this, since they are presented with a one-sided, military aspect of the blockade (personal communication, interviewee K, 30th January 2020). Harsh actions of the Soviet government against its own population also remain a sensitive topic that has been left largely unaddressed by the most prominent museums in St Petersburg. The museums that do address these topics are harder to find and - at least in one case - face a certain degree of backlash for their efforts in addressing uneasy questions (personal communication, interviewee L, 29th January 2020).

This seems to be different from the quite prominent "Liberty $\mathrm{Mu}$ seum" in Groesbeek near Nijmegen, which holds a broad outlook on freedom and war and stimulates self-criticism, yet hardly experiences hindrance in portraying its perspective, according to its director (personal communication, interviewee C, 7th April 2020). In both St Petersburg and Nijmegen, museums are currently devoting significant attention to civilian suffering, but in Russia the focus on heroism is still definitely more pronounced. In the Netherlands, this focus amounts to attention for "outside-heroism" by the Allied Powers, which entails the glorification of heroism by the country's liberators. The general tendency is that this focus excludes the Russian Allies, which is something that the "Liberty $\mathrm{Mu}$ seum" tries to correct (personal communication, interviewee C, 7th April 2020). A final observation is that while the reasons for war lie in the interwar period of the 1920s and 1930s, what occurred during those years is barely portrayed in museums. Hence, the Second World War is often regarded by museums as the main event that is to be remembered and taught about. Evidently, this results in an emphasis on military history 
and the war itself, whereas the times leading up to the war are disconnected from the war. In both countries, the pre-war attitude seems to be an uneasy subject. So far, museums and monuments have been discussed, but there are numerous expressions of remembrance culture that fit neither of these categories. These expressions include rituals, some of them combining the symbolism of monuments with the educational elements of museums. Besides the official memorial events, there are many other forms of commemoration rituals. Therefore, the level of society can be divided into state cults, mostly organized around national holidays, and grassroot-initiatives. For St Petersburg, commemoration rituals included many non-governmental events, such as the marathon along the Road of Life. Another example is the visits of veterans and survivors to local schools, clearly combining the communal and private level. It is striking that almost every school in St Petersburg has its own museum related to the blockade. An important observation is that art plays an important role in memorial rituals in both countries. In St Petersburg as well as in Nijmegen, commemorative ceremonies rely significantly on the use of poems and music. For example, a well-known poetry named "Leningrad Poem" (1942), written by Olga Fyodorovna Bergholz, is often referred to in memorial events. As for the 7th symphony titled "Leningrad" by Dmitri Shostakovich can be seen as a significant piece of honor of the besieged city. Although there are many well-known writers and poets about the occupation in the Netherlands, such as Ida Gerhardt ("The Carillon", 1945), popular art seems to play a more important role. Finally, while in the grassroot-initiatives in St Petersburg there was a high degree of attention for civilian suffering, rituals in St Petersburg were slightly more focused on heroism than in Nijmegen. Both military and civilian victims are treated as such in Russian remembrance culture.

This leads to the intermediary conclusion of this paragraph. In Nijmegen civilian victims are predominantly treated as random victims of fate; their deaths are used as narrative devices to remind people of the senselessness of war, in order to propagate a never-again message. What is being honored about these victims is, therefore, not as much their alleged heroism, but predominantly their dreams and ambitions, that were forever erased by the horrors of war. In comparison, in St Petersburg, both military and civilian victims are labelled as heroes. Their stories tend to be connected with a notion of national pride. Privately, some Russian people, expressed a "never-again sentiment" when being asked about the importance of commemoration, but in public places of memory, the never-again motive is not as heavily present as in the Netherlands. In private, some Russian civilians even spoke of their discomfort with the mili- 


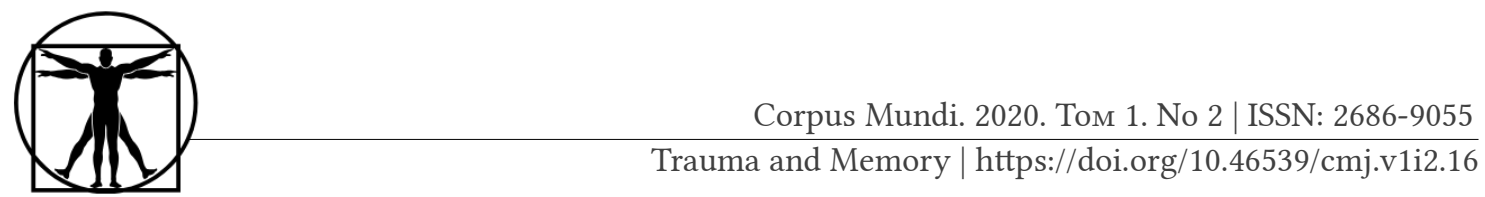

taristic focus of some memorial events, regarding this as promoting questionable values. It should be stressed, however, that these views were discussed in brief "street interviews" and that more research is needed to establish how widely these views are being held.

These distinctions become clearer when taking the context into account. While the people of Leningrad can be said to have endured the blockade, thereby slowing the Nazi advance and "sacrificing" themselves for the country, the people of Nijmegen can be categorized as more "passive" in their victimhood. Both the bombardment and the heavy fighting during Operation Market Garden were relatively short strikes of disaster, that simply "happened" to the population. Because the city was bombed by its allies, no immediate objective was pursued with the suffering of Nijmegen's citizens. It follows that the perspective of heroism has not been applied as vigorously as with the blockade of Leningrad, since the events differ too greatly in impact and in the manner in which they are remembered. Whereas the bombardment was "forgotten," the blockade and the Great Patriotic War are still central to remembrance culture in St Petersburg. Elements of heroism do exist within Dutch remembrance culture, but this applies mostly to "outside-heroes," which is significantly different from the nationalist heroism focused on in Russian remembrance culture. These observations will be explored further in the interview-analysis.

\section{INTERVIEWS: CONVENTIONAL NARRATIVES}

With regard to the current official narrative, almost all Russian interviewees state that this mainly revolves around heroism. In addition, the Soviet state is depicted as flawless, while the state's enemies' actions, and particularly those of Nazi Germany, are emphasized as the major cause of conflict and misery. This military focus is also evident for the Dutch case. As the Dutch interviewee A, a journalist, indicates during his interview, shortly after the Second World War the war was commemorated in a military, "authority-sensitive" way. According to interviewee A, when looking at memorial cemeteries one can truly see how authorities generally commemorate soldiers. Interviewee A explains that one was initially not allowed to blame the American soldiers for the bombardment in Nijmegen and, consequently, damage the heroic image of the American army (personal communication, interviewee A, 4th March 2020). For a long time, this military focus in remembrance tended to overshadow other aspects of the war and it was not until the 1980s that the suffering of Dutch civilians finally received national attention. 
The remembrance culture of both cities has changed significantly ever since, as is visible in museums and monuments. Russian interviewee $\mathrm{B}$, a PhD student, claims that personal stories of the Second World War started to appear thirty years after the Leningrad blockade (personal communication, interviewee B, 30th January 2020). While government-funded museums such as the Museum of the Defense and Siege of Leningrad refrained from these narratives, museums such as the Anna Akhmatova Museum started raising more difficult questions. In Nijmegen, exhibitions of museums also changed from being heroism-centered towards a more inclusive narrative. Interviewee $\mathrm{C}$, a director of a Dutch museum, explains that "this ties in with the fact that those who were children during the Second World War are now retiring and looking back at their childhood" (personal communication, interviewee C, 26th April 2020). While the citizens' narrative is undoubtedly more present this day, interviewee $\mathrm{C}$ argues that there are great differences between generations in their memory of the war. Whereas the older generation tends to hold on to the story of heroism, the younger generation are more malleable. Interviewee $\mathrm{D}$, a professor and researcher at a Dutch university, also states that it is difficult to give meaning to the citizens who died because of the war (personal communication, interviewee D, 10th April 2020).

Although architects initially addressed the concept of victimhood either by interpreting it as part of a heroic struggle or as an example of the enemy's barbarity, interviewee E, a Russian architectural historian, stated that this started to change during the 1960s. An architectural contest, which concerned the building of a new commemorative monument, created an intense debate. There was a high level of public engagement and interviewee $\mathrm{E}$ explained that citizens used this opportunity to express their opinion on the commemoration of the Siege. These competitions arguably showed that a balance was needed between heroism and suffering (personal communication, interviewee E, 30th January 2020). Slowly but surely, traumatic elements of the blockade started to become a part of everyday life for citizens, such as the taboo on wasting food. Bottom-up initiatives of remembrance started to organize events, such as symbolically handing out a piece of bread that symbolizes the amount of bread a Leningrader would have received during the blockade. However, interviewee F, a PhD student at a Russian University, explains that this form of commemoration was highly criticized by the public, "because it simplifies suffering" (personal communication, interviewee F, January 30th 2020). 


\section{INTERVIEWS: RESEARCH CHALLENGES}

With regard to the conventional narratives within the remembrance cultures, experts are not only influenced by this context, but can also be considered "influencers." It could be expected, however, that exercising this influence is not without its challenges, whenever an experts' view clashes with the conventional narrative. Despite these prior expectations, the interviews gave no reason to assume that these challenges extend beyond those research challenges that an expert would consider "part of the job," such as fundraising and the subjectivity of eyewitnesses. Active obstruction of the research process by stakeholders or authorities rarely surfaced as a relevant theme during interviews.

A challenge that was regularly mentioned during the interviews is that of the emotional nature and the historical sensitivity of the subject matter. Both the Leningrad blockade and the bombardment of Nijmegen involve painful stories, and these can personally affect the researcher. For this reason, one expert explicitly stated that he enjoyed the distance that his research perspective on the blockade allowed him to keep from the subject (personal communication, interviewee E, 30th January 2020). The emotional baggage that the research topics entailed increased the sense of responsibility in "representing" the history that both Russian and Dutch experts experienced. This sentiment was often expressed when eyewitnesses were involved in the interviewees' research. Yet, even researchers who used different methodologies described situations where individuals approached them in private about their projects. This led them to become more aware of the importance of their work to others.

The experts emphasized that public reactions to projects were present in both Russia and the Netherlands; there was, however, a difference in the role these public reactions play. In the Netherlands, public reactions sometimes had an "agenda-setting"-function, similar to what one would expect from carrier groups. One clear example of this, mentioned by several Dutch interviewees, was an occasion where a historian from the NIOD ("Dutch Institute for War documentation") publicly stated that all information about Nijmegen during wartime was already available. This statement resulted in a public outcry by inhabitants from Nijmegen, who felt that the case of Nijmegen had not yet been researched enough. The public outrage eventually influenced the Radboud University's decision to make more funds available for historical research on the case of Nijmegen, which resulted in some of the literature that was consulted for this project. 
The function of the public as a carrier group was less visible on the Russian side, although some interviewees mentioned a clear public interest in their endeavors. Most specifically for the architectural contest, the public replied to this event on an incredibly large scale. Even though it was less acceptable to publicly make statements about the conventional narrative of the siege as an individual, this example shows that people did use the means made available to them, in order to try to influence the narrative. Such a level of public interest is nowadays still present with respect to the blockade, as is shown by the interest in interviewee G's documentary. The Dutch film director received both enthusiastic and upset reactions when she screened her documentary in Russia in 2011:

"When I screened the documentary for participants, some were upset because I interviewed someone in my documentary, who spoke of traumatic episodes like the cannibalism that occurred during the blockade. Some participants angrily told me that they felt that these aspects of the blockade should not be spoken of." personal Communication, interviewee G, 11th March 2020

The field research and the thick descriptions confirm the general image of the blockade as an exciting topic to Russians. Furthermore, the blockade is a subject that can greatly divide academics. As interviewee B described:

"Debates sometimes turn into $\mathrm{s}^{* *}$ tstorms, such as when a collection of diaries is published as evidence for research. People then go on to say that what is described is not true".

personal Communication, interviewee B, 30th fanuary 2020

This is an example of how the blockade can also cause strong reactions among more specific groups than the general public. Another example of this was provided by interviewee $C$, who stated that his museum faced public outrage when his museum opened an exhibition on the SS (personal communication, interviewee C, 7th April 2020). This public outrage arose mostly not due to general unwillingness to learn about this subject, but more so due to the influence of interest groups. The exposition tried to transcend the SS's general image by covering endeavors of the SS in homeopathy and archeology. The CIDI ("Centrum Information and Documentation Israel") subsequently criticized the museum heavily for humanizing the SS. However, examples of such a carrier group effectively guarding the boundaries of the conventional narrative were only discussed in a few interviews. This could partly be explained by the more present position museums hold in the media, as opposed to academic research. What should not be forgotten, however, is that many of the inter- 


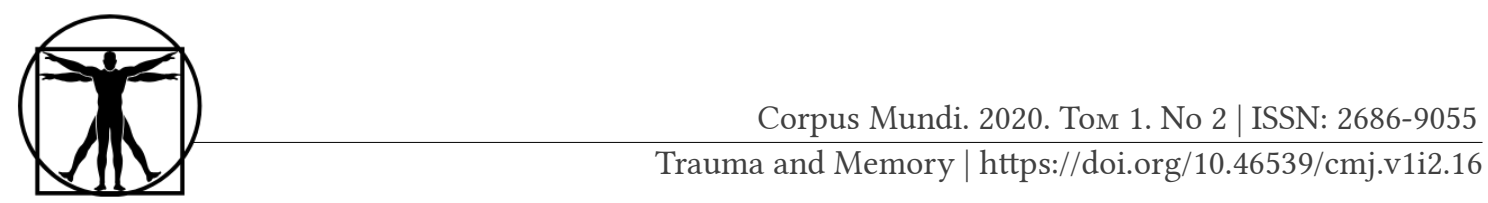

viewed experts also acted as carrier groups themselves, aiming to leave their mark on which aspects of the war are commemorated. Examples include Russian professor interviewee $\mathrm{H}$ who researched instances of criminal behavior in besieged Leningrad, museums in St Petersburg that address crimes of the Soviet regime during the war and interviewee A who wrote extensively about resistance fighters in Nijmegen in the local newspaper.

Almost all interviewees expressed a certain willingness to correct the conventional narrative or address aspects that received too little attention in their opinion. The main difference was the degree of influence these experts had; some were experienced professionals with an extensive network, others had only recently started their careers. These differences had implications for the instruments of influence experts had at their disposal. Interviewee $\mathrm{H}$, for instance, was in a position where he could publish an open letter in a newspaper, and a Dutch professor had been asked to preread a memorial speech by a Dutch government official. These instruments of influence are the most essential factors in explaining how successful experts are in influencing their respective remembrance cultures.

Although most experts indicated that they wanted to "correct" certain faults in remembrance culture, some experts also expressed doubts in doing this. An example was given by another researcher, who knew that a certain resistance "folk hero" had probably not done the things that he was praised for. For this researcher this case prompted questions about the preferability of a positively inspiring myth over the truth (personal communication, interviewee M, 20th January 2020). It should be stressed, though, that these experts still expressed a desire to "correct" the conventional narrative in other instances. Only one researcher explicitly stated that he was not concerned with correcting the conventional narrative, stressing that his research focused more on artistic expressions of remembrance culture than the culture itself (personal communication, interviewee E, 30th January 2020).

\section{INTERVIEWS: UNDERLIT AND UNDERREPRESENTED SUBJECTS}

During the interviews, both Russian and Dutch interviewees believe there to be underrepresented topics as well as an uneven distribution of attention. Most Russian interviewees argued for a better balance between heroism and suffering, which is currently not the case in all museums. Several interviewees argue that whilst this does not apply to all museums, most museums tend to lack individual aspects and give a voice to the citi- 
zens. However, interviewee B mentions an event during which all names of the victims of the war were read out loud. Interviewee B is enthusiastic about this initiative and prefers this way of mourning (personal communication, interviewee B, 30th January 2020). The emphasis on the citizens' narrative is a central theme in both the Russian as well as the Dutch interviews. Although the citizens' narrative of Nijmegen has been receiving quite a lot of attention recently, Interviewee I, a Dutch employee of WO2Gelderland, argues that this does not do justice to the Jewish community. Interviewee I argues that occasionally, the Jewish narrative lacks recognition. Whereas the persecution of the Jewish community receives a great amount of attention in Amsterdam and surrounding cities, Interviewee I argues that this is somewhat different in Nijmegen. Important events such as Market Garden and the Bombardment seem to overshadow the Jewish narrative (personal communication, interviewee I, 2nd April 2020).

Certain "dark pages" of Russian history appear to not be a part of the official blockade narrative. Interviewee F mentions that no "bad stories" were told on differences between ranks, the amount of food one received, disabled people and PTSD cases (personal communication, interviewee F, January 30th 2020). Interviewee $G$ argues that there appears to be little space for the acknowledgement of the traumas they suffered as victims. The problems that come with being traumatized conflict with the bigger picture of being a hero (personal communication, interviewee G, 11th March 2020). Interviewee $\mathrm{H}$ also addresses these dark pages and believes that certain mistakes of the governments do not receive enough attention.

The most critical issues include the delay of liberation, the poorly organized evacuation of civilian population from Leningrad before the siege and in December 1941- January 1942 as well as ill managed work by local authorities to deliver food and other supplies to Leningrad during the first winter of the siege. Several other interviewees also acknowledge this scandal of food rationing and believe that these truths should receive attention (personal communication, interviewee H, 30th January 2020).

This lack of attention for the dark pages, as is present for the case of St Petersburg, applies to Nijmegen as well. An overarching theme in multiple of the Dutch interviews is the focus on whether a person was "right" or "wrong." Even if a person was "wrong," several interviewees believe that these stories and the person's process of decision-making should receive attention as well. The heroic image of the American soldier, for instance, is often a topic of debate in Nijmegen. One of the interviewees argues that one should be allowed to slightly damage the heroic image of the American liberators, as this creates a more accurate memory. 


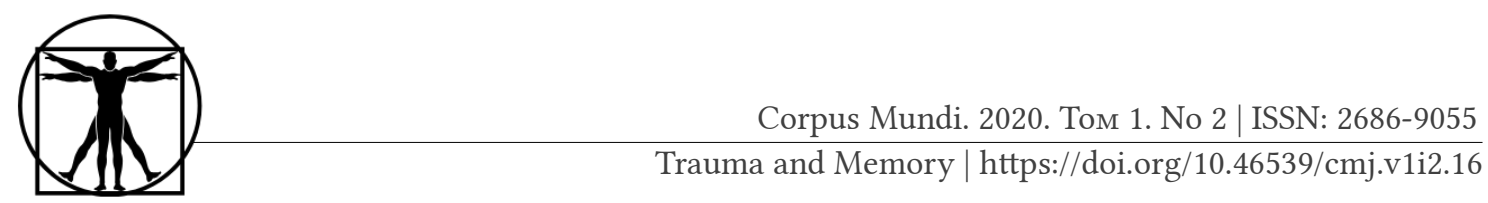

The wrongdoings of certain citizens are not the only mistakes that experts would like to see gain more attention (personal communication, interviewee C, 26th April 2020). Errors by the culture of commemoration itself are also important to acknowledge, according to interviewee A. Interviewee A gives the example of the "stone of Jan van Hoof," who was unjustly celebrated for saving the bridge over the river Waal. While the public is aware of the untruthfulness of the story, interviewee A argues that "by informing the public of the year of the monument's erection, one can learn how the culture of commemoration works. It will then become a story from which we can learn that we can sometimes be wrong" (personal communication, interviewee A, 4th March 2020).

The great emphasis on Germany as the true villain and the lack of consideration of other countries is apparent in several interviews. When remembering the Second World War, several Russian interviewees believe that it is important to re-evaluate the role of participants. Dutch Interviewee $\mathrm{J}$, who is a researcher at university, agrees and states that it is important to put those who conquered the Netherlands into perspective. This will allow for a multi-dimensional story to arise, which in turn will create an international narrative (personal communication, Interviewee J, 15th April 2020). One should allow for the country of Germany to tell their side of the story, because, according to interviewee C, "this will show that there were good and bad guys on both sides of the war" (personal communication, interviewee C, 7th April 2020). This, however, does not function as an excuse for someone's behavior. The interviewee states that "understanding everything is not the same as forgiving everything" (personal communication, interviewee C, 7th April 2020). To understand the complexity of ethics of this war, one should take a look at all sides of the war (personal communication, interviewee C, 7th April 2020).

Both Russian and Dutch interviewees mention the commercial aspect of commemorating the Second World War. Shortly before the 17th anniversary of the siege, many Russian films were made on this topic. Interviewee F explains that "it is pure economics; they take money from the state and make these films just for the anniversary" (personal communication, interviewee F, January 30th 2020). Thus, while in the process of commemoration, films that memorize the Siege also allow for people to earn a living.

The process of commercializing a memory applies to the case of $\mathrm{Nij}$ megen as well. On the 4th and the 5th of May, several events are organized in the Netherlands to remember those who passed away during the war and to celebrate freedom. Interviewee I argues that during such commemorative events, the content and story of the event is often pushed to 
the background whereas the celebration itself is more important. Interviewee I dislikes this and would like for the historical context to be of more significance. However, interviewee I claims that tourism allows for the story to reach a bigger audience (personal communication, interviewee I, 2nd April 2020). Interviewee A also does not feel particularly bothered by the commercial aspect of remembering the Second World War. Interviewee A argues that this is necessary in order for one to remember "the biggest humanitarian disaster of all time" (personal communication, interviewee A, 4th March 2020).

"In celebrating the liberation of Nijmegen, one can feel the pain of the bombardment"

personal communication, interviewee D, 10th April 2020

According to several experts, the story of the Second World War should not only be limited to the actual years during which the war took place. Interviewee $\mathrm{H}$ argues that he would find it interesting if post-war times were presented in exhibitions as well, for example "How did the lives of Russian people change after the Great Patriotic War?" Similarly, two Dutch experts would like to see the years prior to the war gain more attention. Both interviewees would like to see the 1930s receive more attention, as the attitude towards the Jewish community and Germans was incredibly different and less hostile back then (personal communication, interviewee A, 4th March 2020).

In terms of education, several interviewees express their opinion on the way in which schools are currently commemorating the Second World War. Interviewee B claims that children should not be confronted with historical traumatic events at an early age. Therefore, Interviewee B states that in order to avoid traumatizing children, one should slowly allow them to become acquainted with the Siege in a specialized children's museum (personal communication, interviewee B, 30th January 2020). Interviewee $\mathrm{F}$ would also like to see change in the way children are taught about the war. He explains that schoolbooks barely focus upon surrounding cities that also suffered tremendously. Besides the lack of recognition of other cities, interviewee F states that "teachers and books do not deal with trauma. It is clear that the siege did not end happily, but you will not find this in schoolbooks (personal communication, interviewee F, January 30th 2020). Interviewee $F$ also argues that history classes should offer different perspectives and should incorporate the division between the government's management and the citizens' social suffering.

In the Dutch context, interviewee A would like for young adults to learn more about the process of fleeing from the war. One could, accord- 


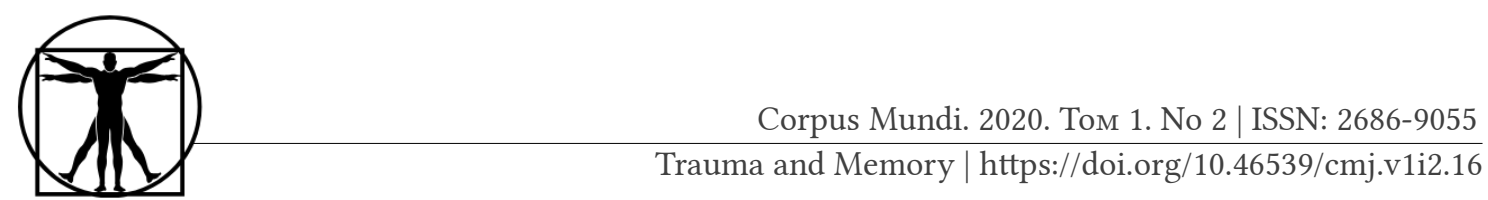

ing to interviewee A, combine this with contemporary issues such as refugees that are currently seeking asylum in Europe (personal communication, Interviewee A, 4th March 2020). Interviewee I finds it important that remember takes place in order to understand the situation the people were in and to prevent such an event from happening ever again (personal communication, Interviewee I, 2nd April 2020). Interviewee D argues that as people and their surroundings are shaped by memories, "remembering is of importance in order to allow oneself to feel connected to one's current residence and thus functions as a mirror and frame of reference" (personal communication, interviewee D, 10th April 2020).

\section{INTERVIEWS: UNEASY QUESTIONS, BLIND SPOTS AND TABOOS}

When this variety of expert opinions is cross-compared and compared to the data of the thick description, it becomes clear that there are several themes that generally appear to be "sore subjects." The role of the Soviet government during the Leningrad blockade is such a troublesome subject. The heroic image of the Soviet government as liberator and victor contrasts with its inactivity and inefficiency in handling the Leningrad blockade. In addition, the efforts of the government to draw away attention from Leningrad after the war, including legal persecutions, remain a sore subject. Particularly, this post-war oppression has added to the traumatic nature of this already traumatic event, increasing the divide between the urban trauma of St Petersburg and the national Russian war trauma. Many Russian museums hesitate to incorporate a critical stance toward government-action during and after the war. The crimes of the Soviet regime are not unknown in any way, but do not fit with the narrative of a heroic past. Another controversial subject that generally seems to conflict with the image of a heroic past, relates to the criminal activities in besieged Leningrad, such as the instances of robbery, murder and cannibalism committed by citizens. While these darker themes were gruesome for those who witnessed them, they can also be traumatic for those who committed the acts. The struggle to retain one's humanity in the worst of times, is a theme that is elaborately discussed in the classic Book of the Blockade (Adamovich \& Granin, 1982), which is compiled from various eye-witness accounts.

In many ways, Nijmegen's situation is quite different from the Leningrad blockade. The assertion that the government undertook criminal activities is not at all controversial, since the pre-war Dutch government was in exile during the war and the country was run by a de-facto 
puppet government of the Nazi regime. After the war, questions about the level of collaboration of government-employees were easily revolved by attributing all collaboration to the NSB ("National-Socialist Movement"), the Dutch equivalent to the Nazi party. Yet, because the Netherlands ranks among the highest when it comes to wartime deportations of its Jewish population, the topic of Nazi-sympathies and collaboration remains an uneasy subject. It is certainly not a "blind spot," since knowledge of this fact is easy to come by, yet, certain aspects of this history receive little attention. Especially when it comes to Nijmegen, several interviewees stress that little is being discussed, for instance, about what happened to its Jewish inhabitants.

This hints at an uneasy question residing in Dutch remembrance culture: the attitude of ordinary Dutch citizens with regard to the antiSemitic measures taken by authorities during the war. This is the case both for the attitude during and after the war. After the war, some survivors of the concentration camps returned to Nijmegen, facing unsympathetic and cold attitudes by the Dutch inhabitants. Interviewee J created a documentary about this phenomenon and stated:

\footnotetext{
"The welcome that the Jewish survivors (returning from the camps) received (from the Dutch people) was cold to the point of hostility. But you can see how the Jewish community arose again after the war to participate in society. The past was pushed away and the future was embraced, despite that being really difficult."
}

personal Communication, Interviewee f, 15th April 2020

After the war, the need to "move on" and rebuild the country created a climate where there was little attention for how non-Jewish citizens treated Dutch Jews during the war. The refusal to deal with the past adds to the notion of urban trauma that this paper engages with.

Another subject that generally seems to receive little attention is the Dutch-German relationship before the war began. Whereas Germany and the Soviet Union were both emerging great powers with ideologies that were hostile towards each other, the Netherlands is Germany's "tiny" neighbor. The level of hostility between Germany and the Soviet Union did not exist between the Netherlands and Germany, and as a result Dutch perceptions of Germany's political developments were not all unfavorable. A National-Socialist movement - the NSB - had already been founded in the Netherlands before the war began. Dutch perceptions of Germany did change during and after the war, but the Dutch attitude toward Nazi ideology before the war is a subject that is currently neither taught at school, nor receives much attention in the remembrance culture 


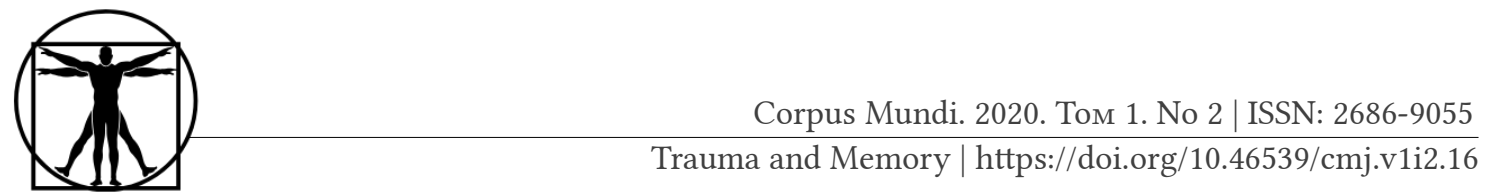

(personal communication, interviewee A, 7th April 2020). Interviewee A mentioned that he did not believe this was due to public unwillingness to learn about the subject, as he received enthusiastic reactions upon addressing it. It is simply a topic that is underlit and therefore not very present within Dutch remembrance culture (personal communication, interviewee A, 4th March 2020). This aspect can therefore be marked as a blind spot.

Finally, the bombardment of Nijmegen itself remains an uneasy question. After the war, there was a tendency - also among Nijmegen's own inhabitants - to see the ordeal as a sacrifice for the greater good of liberation. This contrasts heavily with the bombardment of Rotterdam, which can more easily be acknowledged as a war crime by the Nazi regime. Even though recent research has shown that the bombardment of Nijmegen was most likely not accidental (Rosendaal, 2009), the view of it being an accident is still widely held. In addition, it could be stated that the nationally underlit case of the bombardment of Nijmegen still takes the limelight when compared to the city's liberation in the fall of 1944. This ordeal is often glanced over as part of the greater picture of Operation Market Garden. Therefore, some older inhabitants experience the amount of attention for bombardment-victims as disproportionate when compared to the victims of the liberation (personal communication, interviewee $\mathrm{D}$, 30th November 2019). With regard to the liberation, the heroic image of the Allied powers as our liberators clouds the stories of certain less favorable actions by liberating soldiers, such as looting. These latter details can be said to be part of a true blind spot within Dutch remembrance culture, since these aspects are rarely discussed. The Leningrad blockade and the bombing of Nijmegen thus relate to one another in some respects. For example, just as with the liberation of Nijmegen, the ordeal that Leningrad's inhabitants experienced is also viewed as a sacrifice for the greater good. Furthermore, the argument that the horrific events could have been prevented if a supposed "friendly" government had made different choices can be made for both Nijmegen and Leningrad. For both this observation is - if not a taboo - definitely an uneasy question.

\section{CONCLUSION: REMEMBERING URBAN TRAUMA}

One major similarity between St Petersburg and Nijmegen is that the ordeals the cities went through were not proportionally acknowledged on a national level after the war was over. This is arguably why these ordeals constitute "urban traumas," existing parallelly to the national traumas of the Second World War. When comparing the data from St Petersburg and 
Nijmegen, there seems to be another major similarity: both countries have seen a development of remembrance culture from being predominantly military-oriented towards more acknowledgment of civilian suffering during the war. What is different, however, is that within Russian remembrance culture, soldiers and civilians alike tend to be portrayed as "heroes" who made a sacrifice for their motherland. This focus on the heroic aspect of the Leningrad blockade is visible in monuments, museums, memorial events and many other expressions of remembrance culture. Although there arguably is ample reason to speak about heroism when addressing the Leningrad blockade, this heroic focus tends to exclude less heroic - and more traumatic - aspects of survival during the blockade. These dark and traumatic elements do not fit the heroic narrative and are, therefore, predominantly left to be addressed by experts who actively research the subject.

In addition, the conventional view that the Leningrad blockade was a heroic sacrifice for the greater good of Soviet victory, is not easily reconciled with some difficult questions of Soviet history. While there are museums that address these traumas, they are far from the most prominent ones and addressing this theme is not without its share of negative consequences and public backlash.

When it comes to the case of Nijmegen, Dutch remembrance culture regards the civilian victims not as much as heroes, but as "random victims of fate." Exceptions to this rule are the resistance fighters who died during the war. The memory of civilian suffering is not as much used to invoke a feeling of Dutch nationalism or heroism, but predominantly to remind people of the senselessness and the horrors of war. Within this frame, the bombardment of Nijmegen is treated as an example of how the war took away innocent lives and dreams, therefore serving a "never-again"-motive within Dutch remembrance culture. Like in Russia, there is plenty of justification for the conventional Dutch perspective on wartime civilians as innocent victims: during the war, the Netherlands were governed by a Nazi puppet government, while the "official" Dutch government was in exile.

Furthermore, wartime destruction - such as the bombardment of Nijmegen - was carried out by foreign authorities and, therefore, simply "happened" to the victims. This conventional perspective, however, excludes its own set of uneasy questions, such as the Dutch pre-war attitude towards Nazism and the Dutch attitude towards its Jewish population during and after the war. This latter category involves acts of collaboration, betrayal and post-war hostility against Jews. Especially in provincial cities such as Nijmegen, the Dutch treatment of its Jewish population is a 


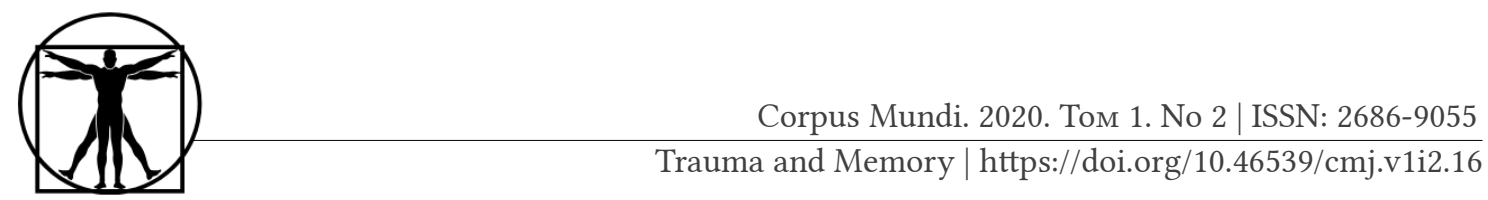

subject that receives relatively little attention. In addition, whereas the Holocaust receives a lot of attention in education and media, the post-war experience of the Jews who returned is a trauma of its own; one that receives strikingly little attention within Dutch remembrance culture. Finally, the bombardment and liberation of Nijmegen include many traumatic episodes, of which some still attract little attention. While in Russia the actions of the government remain a controversial issue, the same goes in the Netherlands for some actions of the Allied powers. These include instances of looting by Allied soldiers, but also the deliberate targeting of Dutch cities during bombing raids.

\section{CONCLUSION: EXPERTS' INFLUENCE}

The Russian and Dutch remembrance cultures greatly influence what traumas the general public remembers and what it "forgets." Experts, however, are not merely part of this remembrance culture, but also contribute to it. They do this by highlighting those aspects of the Second World War that they deem important and underexposed. Through the interview data, it becomes clear that both in Russia and the Netherlands experts are highly opinionated when it comes to the way the Second World War is remembered in their country. Experts can, therefore, clearly be said to function as carrier groups. It should be stressed that experts also respond to carrier groups. There were several cases - mostly among Dutch experts - in which interviewees spoke of their research agenda being influenced by the general public. Nearly all experts viewed correcting the "faults" in remembrance culture as part of their role. Motivations that were often discussed were the need to get a "more complete picture of the war," to acknowledge human suffering and the need to learn from the past. In addition, one expert mentioned the economic motive of organizing museum-exhibitions on underexposed topics. Different from what was expected at the beginning of this project, experts from both countries did not experience extraordinary challenges in fulfilling their meaning-making role. Challenges in doing or publishing research mostly amounted to challenges that are considered "part of the job." A more extraordinary challenge can be said to be the higher level of public involvement and scrutiny that comes with researching sensitive historical subject matter. This was, however, in many instances also experienced as inspiring, as stated earlier.

Success in effectively contributing to the meaning-making process seemed to depend more on the status and the type of medium of an expert. Some of the experts had already had long careers and consequently had 
larger networks. As a result, they had more instruments of influence at their disposal, than experts who had only just started their careers and hence - worked more "behind the scenes." While all media - from museum expositions to academic publications - have some potential in leaving a mark on remembrance culture, there is a degree of difference in how much they appeal to the general audience. In addition, those experts that can "cast a wider net" have a larger chance of having an impact on remembrance culture, than those who are limited to - for instance - academic publications. This status-difference can, thus, be said to be a more prominent factor for experts while interacting with remembrance culture, than challenges or obstructions encountered during the research process.

\section{DISCUSSION: OPPORTUNITIES AND LIMITATIONS}

During this research project, there were several practical limitations that influenced its course. One of these practical limitations relates to the planning of the interviews with Russian experts. These interviews all had to take place within one week. Because of this time span, but also distance- and language-difficulties, the Russian group of interviewees was not as heterogeneous as in The Netherlands. Most experts that were interviewed in St Petersburg were academic experts from one of the local universities, whereas in the Netherlands a larger variety of experts was spoken with. This made a perfect comparison between experts from the two cities unfeasible, even though there were still many aspects by which to compare. The function of the public as a carrier group was less visible on the Russian side, although some interviewees mentioned a clear public interest in their endeavors. It should be emphasized that - due to practical reasons - Russian interviewees only included academic researchers, and no journalists or museum directors. Hence, it is arguably logical that public reactions differed for these interviewees, since academic publications probably reach a smaller audience than, for example, popular media outlets. In addition, it should be noted that the fact that Russians replied on such a large scale during the mentioned architectural contests of the 1960 s, is also an example of the general public functioning as a carrier group. Even though it was less acceptable to publicly make statements about the conventional narrative of the siege as an individual, this example shows that people did use the means made available to them, in order to try to influence the narrative.

Finally, in comparing Russia and The Netherlands, our Dutch backgrounds implied a risk of research bias. In the research design, we made several adjustments to avoid this bias. Firstly, we applied triangulation by 


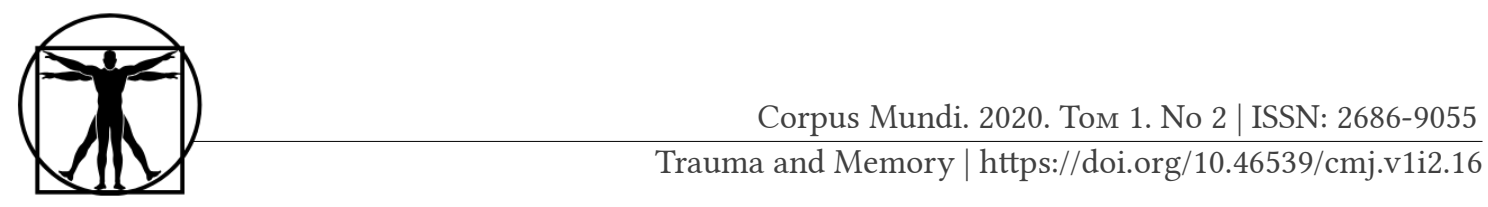

using two kinds of research methods, namely field research and interviews. This allowed us to cross-compare data and corroborate findings acquired by one research method, with findings from the other research method. In addition, it was vital to the impartiality of our project that we conducted field research in St Petersburg. There is nothing as revealing about one's personal bias than experiencing a significantly different culture. This experience not only helped us in understanding Russian remembrance culture, but also in understanding the Dutch remembrance culture that we had grown so used to.

\section{DISCUSSION: SUGGESTIONS FOR FUTURE RESEARCH}

Regarding further research we have to distinguish between researching the Second World War, in general, and the comparative cases of Nijmegen and St Petersburg preceding, during, and after the war. Nevertheless, the more general observations concerning the war can often be applied to the two cities. Hence, the recommendations regarding the war itself can also apply to possibilities for further research with respect to both cities.

With regard to the war itself, we recommend emphasizing civilians' narratives, since the bulk of research and attention thus far has focused primarily on the military and political history of the war; even the attention paid to the Holocaust does not cover the social history genre sufficiently. This is true for academic research, but also for remembrance culture, and relates, for example, to museums, monuments, and popular culture.

Also, the relationship and differences between government and individuals provides for interesting research topics. It serves to recognize differences between the government narrative that is presented in certain areas of study, for example regarding government-funded museums versus that of civilians, which is presented via "independent" grassroots-initiatives. This might lead a researcher to distinguish, for example, between the history of a nation's politically important region, such as Amsterdam in the Netherlands or St Petersburg in Russia versus less populous cities such as Nijmegen, or even rural areas in general. On a micro-level, this also applies to areas within areas, for example less-developed neighborhoods in cities, or neighborhoods in which there reside people with one specific ethnicity or other divergent identity.

Regarding identities, destruction by war returns as a more general theme in research, and clearly differs depending on what is remembered and what not. For example, the destruction of Nijmegen still has conse- 
quences for the manner in which the city and its people regard themselves, and the Leningrad blockade definitely influences its contemporary inhabitants. Yet, whereas St Petersburg's identity with regard to the war is pervaded of pride, because it withstood the siege for so long and its inhabitants experienced horrific daily scenes, the long-lasting silence with regard to the destruction of Nijmegen together with its liberation by foreign actors ensures that the city's identity with regard to the war is not necessarily one of pride and self-esteem. Furthermore, besides the pride and forgetfulness, there is also the more tangible loss caused by destruction, such as torn-apart families, architectural loss, and what we defined in general as "urban trauma."

Concerning this trauma, uneasy questions always return, both on the government level as on the civilian level. With respect to the war itself, the manner in which the Soviet government handled the situation in Leningrad deserves further attention. The relationship between the Leningrad government and the central government in Moscow, for example, or the manner in which Leningrad's government handled food rationing and the evacuation process of its own inhabitants. On the civilian level, the conduct of civilians in St Petersburg remains an uneasy question, especially because it de-legitimizes the dominant heroic narrative. The circumstances of almost three years of besiegement naturally entail a fight to survive, individually but also between civilians. Hence, academic and eye-witness sources have established certain "wrongdoings" by civilians in Leningrad, such as the occurrence of cannibalism and theft. These, and perhaps more, can be summarized by the theme of "ethics of war," and deserve to be further examined.

The notion of ethics introduces a more practical topic that returned often during our trip to St Petersburg, namely the question of how to teach history to schoolchildren. In relation to this, some Russian civilians privately discussed their discomfort with the militaristic nature of some commemorative rituals, which sometimes involved children. Privately, these Russian people expressed a "never-again sentiment" when speaking about commemoration of the war, much similar to the dominant sentiment in the Netherlands. It should be stressed, however, that these views were discussed in brief "street interviews" and that more research is needed to establish how widely certain views are being held, both in Russia and the Netherlands. The specific question of how to educate children, however, returned more often.

Both in-school museums that we visited and our St Petersburg guide emphasized the importance of presenting a more inclusive narrative regarding the blockade, yet hesitated to approve an inclusive story in, for 
example, school curriculums. This relates to the broader question of how to teach children about war and suffering, which is a topic that is not exclusively reserved for classrooms, but should also be included when talking about, and researching, pedagogy in the domestic sphere. Finally, this upbringing includes educating both children and adults about the story of the Second World War, including that of the pre-war and post-war years.

References

Adamovich, A. \& Granin, D. (1982). A Book of The Blockade. Moscow: Raduga Publishers.

Alexander, J.C. (2004). Toward a Theory of Cultural Trauma. In J. C. Alexander, R. Eyerman, B. Giesen, N. J. Smelser, and P. Sztompka (Eds.) Cultural Trauma andCollective Identity (pp. 1-30). Berkeley: University of California Press.

Bambrough, R. (1994). Gilbert Ryle: Collected Papers. Philosophy, 69(269), 376-378. Doi:10.1017/S0 031819100047124

Boukharaeva, L. M., \& Marloie, M. (2015). A New Civil Right Won Under the Soviet Regime. In: Family Urban Agriculture in Russia (pp. 47-73). Springer, Cham.

DiCicco-Bloom, B., \& Crabtree, B. F. (2006). The qualitative research interview. Medical Education, 40, 314-321. Doi: 10.1111/j.1365-2929.2006.02418.x

Eyerman, R. (2011). Intellectual and cultural trauma. European fournal of Social Theory, 14(4), 354-367. Doi: 10.1177/1368 431011417932

Eyerman, R. (2012). Harvey Milk and the Trauma of Assassination. Cultural Sociology, 6(4), 399-421. Doi: 10.1177/1 749975512445429

Eyerman, R. \& Bartmanski, D. (2011). The Worst Was the Silence: The Unfinished Drama of the Katyn Massacre. In R. Eyerman, J.C. Alexander, and E.B. Breese (eds.) Narrating Trauma: On the Impact of Collective Suffering. New York: Paradigm.

Flick, U. (2002). Qualitative research in psychology: A textbook. London: Sage.

Geertz, C. (1973). The Interpretation of Cultures: Selected Essays. New York: Basic Books.

Gerhardt, I. (1946). Het carillon. In Uitgeverij C.A. Mees Wereldbibliotheek N.V Het Veerhuis. Santpoort / Amsterdam (oorspr. 1945).

Ginkel van, R. (2011). Rondom de stilte. Herdenkingscultuur in Nederland. Amsterdam.

Haan, De. I. (1997). Na de Ondergang: De herinnering aan de fodenvervolging in Nederland, 1945-1995. Den Haag: SDU Uitgevers.

Halbwachs, M. (1980). The collective memory. New York, NY: Harper \& Row.

Hill, C. E., Knox, S., Thompson, B. J., Williams, E. N., Hess, S. A., \& Ladany, N. (2005). Consensual qualitative research: An update. Journal of Counseling Psychology, 52, 196-205. Doi: 10.1037/0022-0167.52.2.196 
Hill, C. E., Thompson, B. J., \& Williams, E. N. (1997). A guide to conducting consensual qualitative research. The Counseling Psychologist, 25, 517-572. Doi: 10.1177/0011000097254001

Hirsch, M. (2012). The Generation of Post Memory: Writing and Visual Culture After theHolocaust. New York: Columbia University Press.

Janssen, B. (2005). De Pijn Die Blijft. Nijmegen: Vantilt.

Kirschenbaum, L. A. (4 September 2006). The Legacy of the Siege of Leningrad, 19411995: Myth, Memories, and Monuments. Cambridge University Press.

Legg, S. (2005). Contesting and surviving memory: space, nation, and nostalgia in Les Lieux de Mémoire. Environment and Planning D: Society and Space. 23(4), 481500. Doi: 10.1068/d0504

Lincoln, Y. S. \& Guba, E. G. (1985). Naturalistic Inquiry. SAGE.

Monument to the Heroic Defenders of Leningrad. (n.d.). Retrieved from http://www.saint petersburg.com/monuments/heroic-defenders/

Neal, A.G. (1998). National Trauma and Collective Memory: Major Events in the American Century. Armonk: M.E. Sharpe.

Nora, P. (1989). Between Memory and History: Les Lieux de Mémoire. Representations, 26, 7-24.

Pennebaker, J., \& Gonzales, A. (2009). Making history: Social and psychological processes underlying collective memory. In P. Boyer \& J. Wertsch (Eds.), Memory in mind and culture (pp. 171-193). Cambridge, UK: Cambridge University Press.

Rosendaal, J. (2014). The destruction of Nijmegen, 1944: American bombs and German fire. Nijmegen: Vantilt Publishers.

Smelser, N.J. (2004). Psychological Trauma and Cultural Trauma. In J.C. Alexander, R. Eyerman, B. Giesen, N.J. Smelser and Sztompka (Eds). Cultural Trauma and Collective Identity (pp. 31-59). Berkeley: University of California Press.

Verzetsmonument "De Vaandeldrager." (n.d.). Retrieved from https://www.tracesofwar.nl/sights/331/Verzetsmonument-De-Vaandeldrager.htm

Vivian, B. (2017). “Chapter 3 - Regret: George W. Bush's Gorée Island Address.” Commonplace Witnessing: Rhetorical Invention, Historical Remembrance and Public. Culture. Oxford: Oxford Scholarship Online.

Woods, E. T. (2019). Cultural Trauma: Ron Eyerman and the founding of a new research paradigm. American fournal of Cultural Sociology, 7, 260-274. Doi: $10.1057 / \mathrm{s} 41$ 290-019-00 071-0 
Adamovich, A. \& Granin, D. (1982). A Book of The Blockade. Moscow: Raduga Publishers.

Alexander, J.C. (2004). Toward a Theory of Cultural Trauma. In J. C. Alexander, R. Eyerman, B. Giesen, N. J. Smelser, and P. Sztompka (Eds.) Cultural Trauma andCollective Identity (pp. 1-30). Berkeley: University of California Press.

Bambrough, R. (1994). Gilbert Ryle: Collected Papers. Philosophy, 69(269), 376-378. Doi:10.1017/S0 031819100047124

Boukharaeva, L. M., \& Marloie, M. (2015). A New Civil Right Won Under the Soviet Regime. In: Family Urban Agriculture in Russia (pp. 47-73). Springer, Cham.

DiCicco-Bloom, B., \& Crabtree, B. F. (2006). The qualitative research interview. Medical Education, 40, 314-321. Doi: 10.1111/j.1365-2929.2006.02418.x

Eyerman, R. (2011). Intellectual and cultural trauma. European fournal of Social Theory, 14(4), 354-367. Doi: 10.1177/1368431011417932

Eyerman, R. (2012). Harvey Milk and the Trauma of Assassination. Cultural Sociology, 6(4), 399-421. Doi: 10.1177/1749975 512445429

Eyerman, R. \& Bartmanski, D. (2011). The Worst Was the Silence: The Unfinished Drama of the Katyn Massacre. In R. Eyerman, J.C. Alexander, and E.B. Breese (eds.) Narrating Trauma: On the Impact of Collective Suffering. New York: Paradigm.

Flick, U. (2002). Qualitative research in psychology: A textbook. London: Sage.

Geertz, C. (1973). The Interpretation of Cultures: Selected Essays. New York: Basic Books.

Gerhardt, I. (1946). Het carillon. In Uitgeverij C.A. Mees Wereldbibliotheek N.V Het Veerhuis. Santpoort / Amsterdam (oorspr. 1945).

Ginkel van, R. (2011). Rondom de stilte. Herdenkingscultuur in Nederland. Amsterdam.

Haan, De. I. (1997). Na de Ondergang: De herinnering aan de fodenvervolging in Nederland, 1945-1995. Den Haag: SDU Uitgevers.

Halbwachs, M. (1980). The collective memory. New York, NY: Harper \& Row.

Hill, C. E., Knox, S., Thompson, B. J., Williams, E. N., Hess, S. A., \& Ladany, N. (2005). Consensual qualitative research: An update. Fournal of Counseling Psychology, 52, 196-205. Doi: 10.1037/0022-0167.52.2.196

Hill, C. E., Thompson, B. J., \& Williams, E. N. (1997). A guide to conducting consensual qualitative research. The Counseling Psychologist, 25, 517-572. Doi: 10.1177/0011000097254001

Hirsch, M. (2012). The Generation of Post Memory: Writing and Visual Culture After theHolocaust. New York: Columbia University Press.

Janssen, B. (2005). De Pijn Die Blijft. Nijmegen: Vantilt.

Kirschenbaum, L. A. (4 September 2006). The Legacy of the Siege of Leningrad, 19411995: Myth, Memories, and Monuments. Cambridge University Press. 
Legg, S. (2005). Contesting and surviving memory: space, nation, and nostalgia in Les Lieux de Mémoire. Environment and Planning D: Society and Space. 23(4), 481500. Doi: $10.1068 / \mathrm{d} 0504$

Lincoln, Y. S. \& Guba, E. G. (1985). Naturalistic Inquiry. SAGE.

Monument to the Heroic Defenders of Leningrad. (n.d.). Retrieved from http://www.saint petersburg.com/monuments/heroic-defenders/

Neal, A.G. (1998). National Trauma and Collective Memory: Major Events in the American Century. Armonk: M.E. Sharpe.

Nora, P. (1989). Between Memory and History: Les Lieux de Mémoire. Representations, 26, 7-24.

Pennebaker, J., \& Gonzales, A. (2009). Making history: Social and psychological processes underlying collective memory. In P. Boyer \& J. Wertsch (Eds.), Memory in mind and culture (pp. 171-193). Cambridge, UK: Cambridge University Press.

Rosendaal, J. (2014). The destruction of Nijmegen, 1944: American bombs and German fire. Nijmegen: Vantilt Publishers.

Smelser, N.J. (2004). Psychological Trauma and Cultural Trauma. In J.C. Alexander, R. Eyerman, B. Giesen, N.J. Smelser and Sztompka (Eds). Cultural Trauma and Collective Identity (pp. 31-59). Berkeley: University of California Press.

Verzetsmonument "De Vaandeldrager." (n.d.). Retrieved from https://www.tracesofwar.nl/sights/331/Verzetsmonument-De-Vaandeldrager.htm

Vivian, B. (2017). “Chapter 3 - Regret: George W. Bush’s Gorée Island Address.” Commonplace Witnessing: Rhetorical Invention, Historical Remembrance and Public. Culture. Oxford: Oxford Scholarship Online.

Woods, E. T. (2019). Cultural Trauma: Ron Eyerman and the founding of a new research paradigm. American Journal of Cultural Sociology, 7, 260-274. Doi: 10.1057/s41 290-019-00 071-0 